\title{
Ecological Transition in the Field of Brake Pad Manufacturing: An Overview of the Potential Green Constituents
}

\author{
Giovanna Gautier di Confiengo * and Maria Giulia Faga
}

Citation: Gautier di Confiengo, G.; Faga, M.G. Ecological Transition in the Field of Brake Pad

Manufacturing: An Overview of the Potential Green Constituents.

Sustainability 2022, 14, 2508. https:// doi.org/10.3390/su14052508

Academic Editors: Mostafa Ghasemi Baboli and Asterios Bakolas

Received: 11 November 2021

Accepted: 17 February 2022

Published: 22 February 2022

Publisher's Note: MDPI stays neutral with regard to jurisdictional claims in published maps and institutional affiliations.

Copyright: (C) 2022 by the authors. Licensee MDPI, Basel, Switzerland. This article is an open access article distributed under the terms and conditions of the Creative Commons Attribution (CC BY) license (https:// creativecommons.org/licenses/by/ $4.0 /)$.
Institute of Sciences and Technologies for Sustainable Energy and Mobility (STEMS), National Research Council of Italy (CNR), Strada delle Cacce 73, 10135 Turin, Italy; mariagiulia.faga@stems.cnr.it

* Correspondence: giovanna.gautier@stems.cnr.it

\begin{abstract}
Nowadays, the drive for green products has undergone a rapid increase following the global ecoawareness and the severe regulations aimed at preventing the environment from further damage. The use of ecosafe constituents in materials for harsh applications, such as brake pad systems, can be a possible solution for reducing health hazards arising from particle release during braking. Based on this, the present study provides a bibliographic review of green alternative constituents for friction material formulation, focusing the attention on their influence on the tribological properties of the final composites. The traditional materials still used in commercial brake pads are shortly described, with the aim to provide an overview of the current situation. In the final part of the review, following the trend of circular economy, works dealing with the use of waste as an ingredient of friction materials are also reported. The whole literature screening points out that much work is still required to obtain completely green friction materials. Indeed, few works dealing with the phenolic resin replacement, proposing inorganic ecosafe materials such as geopolymers, are present. On the contrary, the use of natural fibers is widely investigated: palm kernel, flax, agave and aloe can be identified as promising constituents based on the literature results and the generated patents.
\end{abstract}

Keywords: friction material; green constituents; tribology; natural fiber composites

\section{Introduction}

\subsection{Particulate Matter}

Particulate matter (PM) consists of microscopic liquid and solid particles suspended in air whose dimension and chemical composition change continually [1,2]. Because of the extremely large dimension range, which varies from a few nanometers to ten microns, particle behavior in the human respiratory system changes. Particles with size below $10 \mu \mathrm{m}$ can be a potential risk for the trachea-bronchial and alveolar regions [3]. They are subdivided into two groups: (i) coarse, having an aerodynamic diameter ranging from 2.5 to $10 \mu \mathrm{m}\left(\mathrm{PM}_{10-2.5}\right)$, and (ii) fine, with diameter below $2.5 \mu \mathrm{m}\left(\mathrm{PM}_{2.5}\right)$ [4], able to reach alveoli and terminal bronchioles [5]. PM toxicity depends on several factors such as geographic location, season, weather conditions and chemical composition of the different PM fractions [6]. Coarse ambient particles are typically of natural type, i.e., basically primary pollutants, while the finest $\left(\mathrm{PM}_{2.5}\right)$ originate from human activity and consequently are more toxic [7]. For this reason, $\mathrm{PM}_{2.5}$ was advised by the World Health Organization (WHO) to be used as an air quality indicator. An epidemiologic study demonstrated that a $10 \mu \mathrm{g} \cdot \mathrm{m}^{-3}$ increase in $\mathrm{PM}_{2.5}$ is associated with a $1.04 \%$ intensification in the risk of death [8]. In order to safeguard citizens' health, air quality standards have been developed by governmental agencies. In 1987, the WHO developed quality guidelines, followed by updates in 1997 and in 2006, recommending maximum levels of several critical air pollutants that can have negative effects on human health. WHO guidelines, which formerly were addressed to Europe, have been globally extended and implemented, adding three interim targets (IT) [9] which provide a gradual approach to reach the targeted air 
quality index value [10]. In 1971, the Environmental Protection Agency (EPA) established the criteria for PM: a maximum daily concentration of $260 \mu \mathrm{g} / \mathrm{m}^{-3}$ more than one day per year and an annual mean concentration lower than $75 \mu \mathrm{g} / \mathrm{m}^{-3}$ [11]. Later, the EPA introduced the first $\mathrm{PM}_{10}$ limit and, in 1997, the subdivision of $\mathrm{PM}_{10}$ and $\mathrm{PM}_{2.5}$ [12]. Table 1 reports standard values of PM settled by the WHO and U.S. Environmental Protection Agency (EPA) which established the National Ambient Air Quality Standards (NAAQS).

Table 1. Standard values of PM defined by WHO and National Ambient Air Quality Standards (NAAQS) (USAEPA).

\begin{tabular}{|c|c|c|c|c|c|}
\hline Indicator & Averaging Period & Level & Primary/Secondary & Form & Agency \\
\hline $\mathrm{PM}_{10}$ & $24 \mathrm{~h}$ mean & $150 \mu \mathrm{g} / \mathrm{m}^{3}$ & $\begin{array}{l}\text { Primary and } \\
\text { Secondary }\end{array}$ & $\begin{array}{c}\text { Not to be exceeded on more } \\
\text { than once per year on average } \\
\text { over a 3-year period }\end{array}$ & \multirow{4}{*}{$\begin{array}{c}\text { NAAQS EPA }^{1} \\
{[13]}\end{array}$} \\
\hline \multirow{3}{*}{$\mathrm{PM}_{2.5}$} & Annual mean & $12 \mu \mathrm{g} / \mathrm{m}^{3}$ & Primary & Averaged over 3 years & \\
\hline & Annual mean & $15 \mu \mathrm{g} / \mathrm{m}^{3}$ & Secondary & Averaged over 3 years & \\
\hline & $24 \mathrm{~h}$ & $35 \mu \mathrm{g} / \mathrm{m}^{3}$ & $\begin{array}{l}\text { Primary and } \\
\text { secondary }\end{array}$ & $\begin{array}{l}\text { Annual arithmetic mean, } \\
\text { averaged over } 3 \text { years }\end{array}$ & \\
\hline \multirow{2}{*}{$\mathrm{PM}_{10}$} & Annual & $20 \mu \mathrm{g} / \mathrm{m}^{3}$ & - & - & \multirow{4}{*}{$\begin{array}{c}\mathrm{WHO}^{2} \\
{[13]}\end{array}$} \\
\hline & $24 \mathrm{~h}$ & $50 \mu \mathrm{g} / \mathrm{m}^{3}$ & - & - & \\
\hline \multirow{2}{*}{$\mathrm{PM}_{2.5}$} & Annual & $10 \mu \mathrm{g} / \mathrm{m}^{3}$ & - & - & \\
\hline & $24 \mathrm{~h}$ & $25 \mu \mathrm{g} / \mathrm{m}^{3}$ & - & - & \\
\hline
\end{tabular}
Organization.

Principal PM constituents usually include nitrates, sulphates, elemental and organic carbon, organic compounds (e.g., polycyclic aromatic hydrocarbons) and biological compounds [14,15].

\subsection{Pollution from Brake Systems}

The total $\Sigma \mathrm{CO}_{\text {add }}$ emissions from the principal pollutants were computed using Equation (1), where Rt represents the relative toxicity of pollutants relative to carbon monoxide, $\mathrm{m}(\mathrm{i})$ represents mass emissions of that pollutant and $\mathrm{n}$ represents the total number of kinds of pollutants considered.

$$
\sum \mathrm{CO}_{\mathrm{add}}=\sum_{\mathrm{i}=1}^{\mathrm{n}} \mathrm{m}(\mathrm{i}) * \mathrm{R}_{\mathrm{t}}(\mathrm{i})
$$

For petrol-powered passenger cars and electric vehicles (EVs), a $\sum \mathrm{CO}_{\text {add }}$ of $133.9 \mathrm{~g} / \mathrm{km}$ was measured for Euro0, while 4.7 was the measurement for EVs. It is worth noting that a Rt of 150 was calculated for $\mathrm{PM}_{2.5}$ originating from friction materials, ranking them in the first quartile among the 64 pollutants considered in the Klimenko's study [16]. Considering the total $\mathrm{PM}_{2.5}$ emissions in urban areas, particles derived from traffic (automotive sector) (Figure 1) are responsible for up to 50\% of them [17]. Exhaust emissions, which result from partial fuel combustion and lubricant evaporation during combustion, are usually separated from nonexhaust emissions, which are caused by tire, brake and road surface wear or by road dust resuspension [18]. Brake wear is one of the key factors, accounting for up to $21 \%$ of total traffic-related $\mathrm{PM}_{10}$ emissions [19]. 


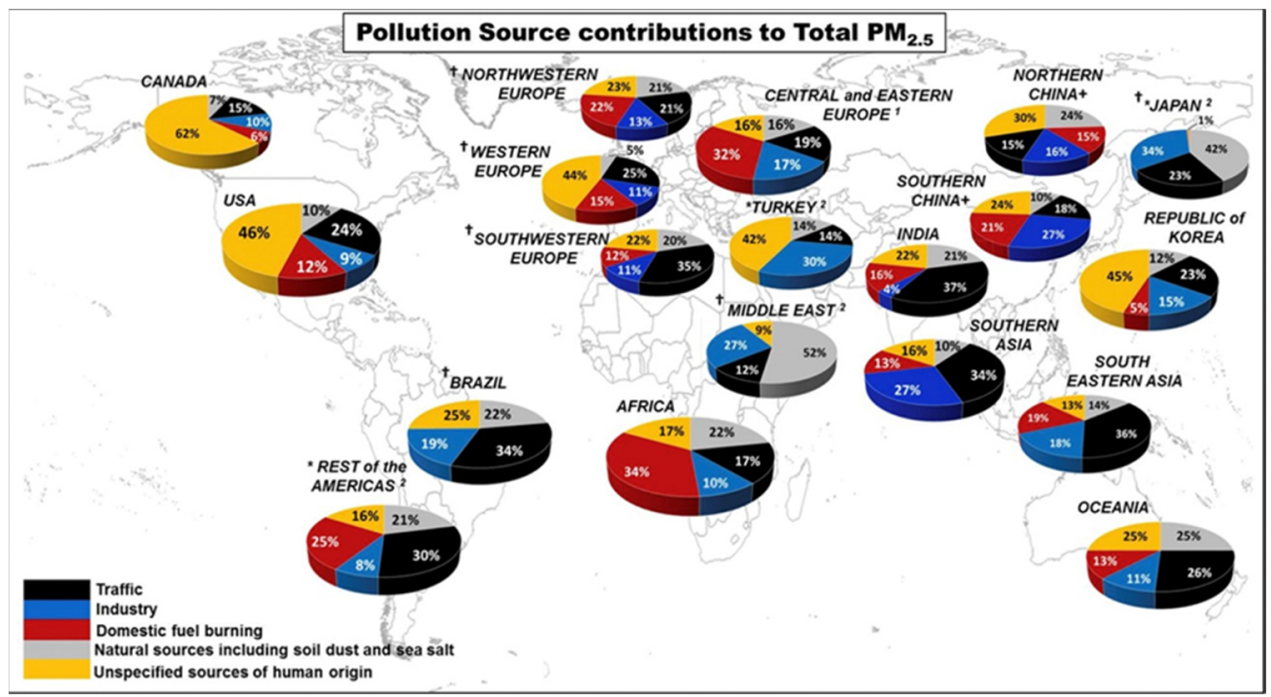

Figure 1. Pollution source contributions to total $\mathrm{PM}_{2.5}$ (courtesy of Karagulian et al. [20]).

Several papers studied the influence of brake system emissions on both the ecosystem and humans. Maiorana et al. evaluated the phytotoxicity of wear particles from both standard (phenolic matrix) and innovative (cement matrix) friction materials. They discovered that the brake pad wear debris (BPWD) produced by the two friction materials had comparable shape, but the traditional friction materials had higher phytotoxicity, resulting in significant root elongation and loss of plasma membrane integrity [21]. Similar phytotoxicity effects of BPWD were reported in lettuce and wheat but not in soybean roots [22]. A comparison between traditional, available-on-the-market brake systems and two innovative, more ecofriendly brake systems, in bench tests revealed that particles from traditional friction materials were not completely safe for edaphic and aquatic ecosystems [23].

Exposure to brake wear particles for human lung cell cultures showed an increase in oxidative stress and a proinflammatory response [24].

Several attempts to reduce the toxicity of particles produced during braking have been made over the years. The first concerns originated in the 1960s, when asbestos fibers were still widely used as important constituents of vehicle friction materials. Asbestos is a fibrous material generally classified into serpentine or amphibole [25]. Serpentine contains chrysotile asbestos, of which the fibers are quite long and flexible with good tensile strength, making them easily woven into fabric for friction materials [26]. Due to its unique characteristics, asbestos became an important component of vehicle friction materials from the beginning of 1900s to the end of 20th century. However, based on various epidemiological studies carried out since the 1960s, asbestos fibers were classified as having a carcinogenic nature by the International Agency for Research on Cancer (IARC). Therefore, since the end of 1980s, several countries world-wide have implemented a gradual asbestos ban. In 1983, Iceland was the first country who completely banned all types of asbestos [27], followed by fifty other countries, while others have developed programs aimed at exposure reduction and abatement of environmental contamination from asbestos. The EPA began taking steps to restrict the use of asbestos in the 1970s. However, friction materials and clutch facings containing asbestos are still currently authorized in the United States (EPA 2018), despite the fact that they are no longer produced and hence in extremely restricted circulation [28].

The asbestos ban led to the production of several friction materials with compositions much more complex with respect to that of asbestos-based materials. Potassium titanate (KT) was considered a potential alternative to asbestos in non-asbestos organic (NAO) FMs [29]. However, due to potential health hazards of the acicular whiskers, use of potassium titanates in commercial friction materials was not promoted. In particular, 
manufacturers of raw materials suggested platy potassium titanate as an alternative to the fibrous shape because it displayed similar wear and fade resistance to fibrous forms [30].

Among the several constituents of the current friction materials, $\mathrm{Cu}, \mathrm{Cd}, \mathrm{Ni}, \mathrm{Pb}, \mathrm{Sb}$ and $\mathrm{Zn}$ are now considered toxic materials necessary to be substituted [31]. Figure 2 shows the trend in the chemical compounds contained in automotive friction materials in the U.S.

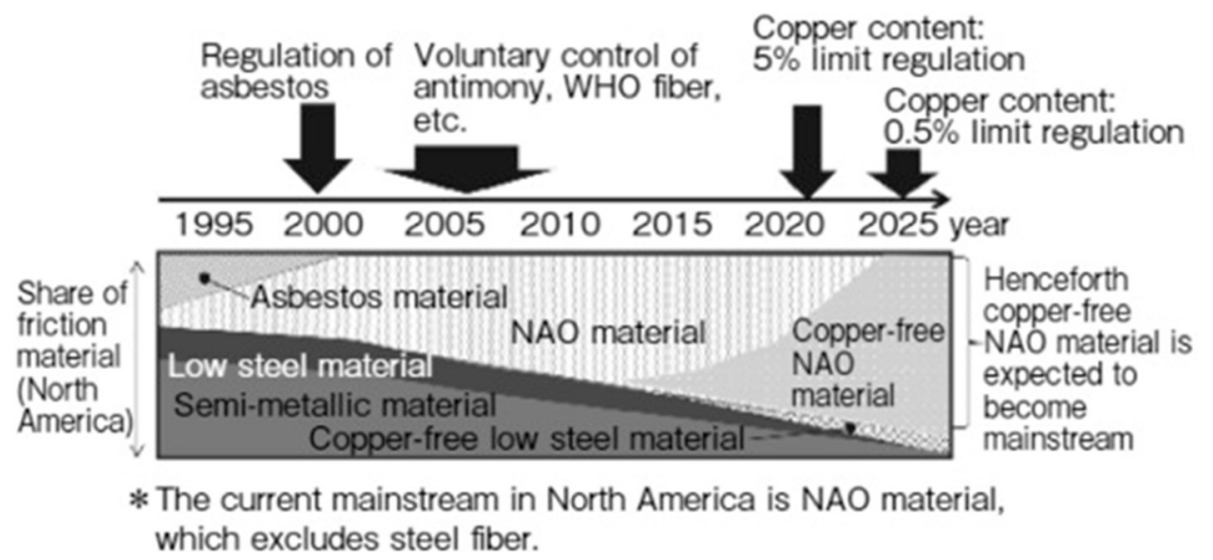

Figure 2. Transformation of chemical compounds in automotive friction materials in the U.S (courtesy of G. Straffelini et al. [32]).

Copper has been one of the most often used components in friction materials. However, it was recognized by the US Brake Pad Partnership that friction materials are the greatest contributors to environmental $\mathrm{Cu}$ pollution [33]. For this reason, U.S. legislation currently limits copper use. Beginning in 2021, friction materials shall include no more than $5 \%$ copper components (low levels), aiming at the amount of $0.5 \%$ by 2025 (no copper materials) [34]. However, the European Union has not enacted a precise regulation on this matter yet. At the moment, it is still possible to use nickel (Ni), antimony (Sb) and zinc (Zn) without restrictions, notwithstanding they are considered harmful elements [35]. In particular, $\mathrm{Sb}$ has attained much attention as a roadside contaminant because it may have hostile effects for humans and the environment [36], entering the human body by skin contact, the food chain and respiration, leading to cell hypoxia [37]. Because of high temperatures occurring during the braking process, some $\mathrm{Sb}_{2} \mathrm{~S}_{3}$ may be oxidized to $\mathrm{Sb}_{2} \mathrm{O}_{3}$, a potentially carcinogenic chemical [38].

Nowadays, ecological transition is a crucial issue in all production sectors, and friction materials cannot be an exception. The present review is attempting to provide an overview of the most common ecofriendly potential constituents in friction material formulation, raising awareness about the research efforts needed in this field for reducing the overall environmental impact of the automotive sector. In the following sections, a state-of-the-art review of the most widely used ingredients for friction material formulation is described, with a classification proposal of the constituents. Indeed, such classification is not unambiguous in research literature, since some materials can belong to different categories. The potential ecofriendly solutions for friction materials are then reported, based on a definition dating back to 1990 [39].

\section{Friction Materials Overview}

The brake pad, rotor and caliper are the three essential components of any braking system (Figure 3a). The role of friction material, that is, the part of the brake pad sliding against the disc (Figure 3b), is to slow and stop a vehicle by converting kinetic energy into heat at the friction material/disc contact in the air. During a braking action, the caliper acts mechanically on the brake pad, which rolls against the disc. Friction materials are subjected to huge frictional heat generation during sliding, resulting in wear of both friction materials and the rotor as well as the formation of particles of various sizes. 


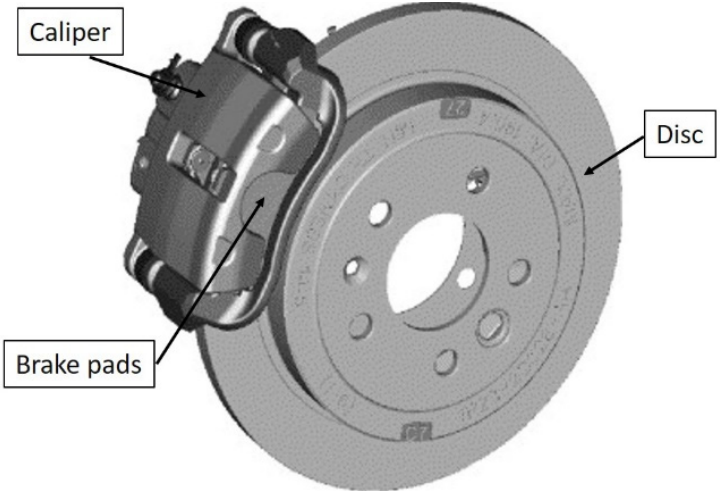

(a)

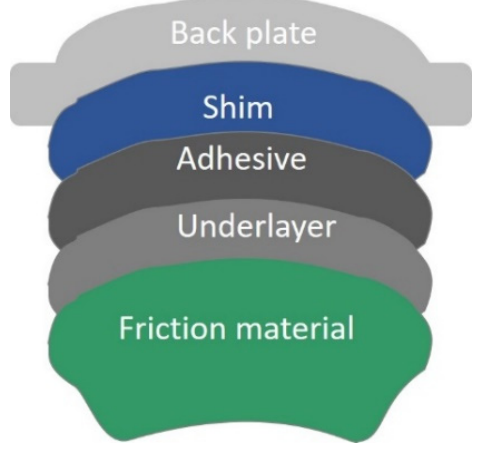

(b)

Figure 3. (a) Sliding disc brake (courtesy of Papinniemi et al. [40]); (b) Brake pad structure.

The most common disc material is grey cast iron, which has excellent thermal characteristics, wear resistance and mechanical strength. Moreover, it is a cheap material easy to machine [41]. There are alternative materials used for discs, such as aluminum-based metal matrix composites, titanium-based materials and ceramic matrix composites based on carbon fibers [42] and matrices of silicon carbide [43]. Disc materials still remain with simpler composition in comparison to friction materials.

The different materials constituting friction materials make their tribosystem very complex and variable. Friction materials are required to: (i) provide a constant coefficient of friction throughout a wide variety of braking situations and (ii) assure a low wear rate at various operating speeds, pressures, temperatures and climatic conditions [44]. Additionally, friction materials must be suitable for limiting vibration and noise while braking and must be resistant to both heat [45] and water [46].

The constituents of friction materials can be greater than one hundred and belong to all materials classes, i.e., metallic, ceramic and organic. Their constituents (Figure 4) are generally classified as binders, fibers, fillers (inert and functional) and friction modifiers (abrasives and lubricants), depending on the role they play in the friction materials: controlling the friction coefficient, improving fade resistance, reducing porosity and noise or increasing strength. Some compounds have various functions and can belong to more than one category.

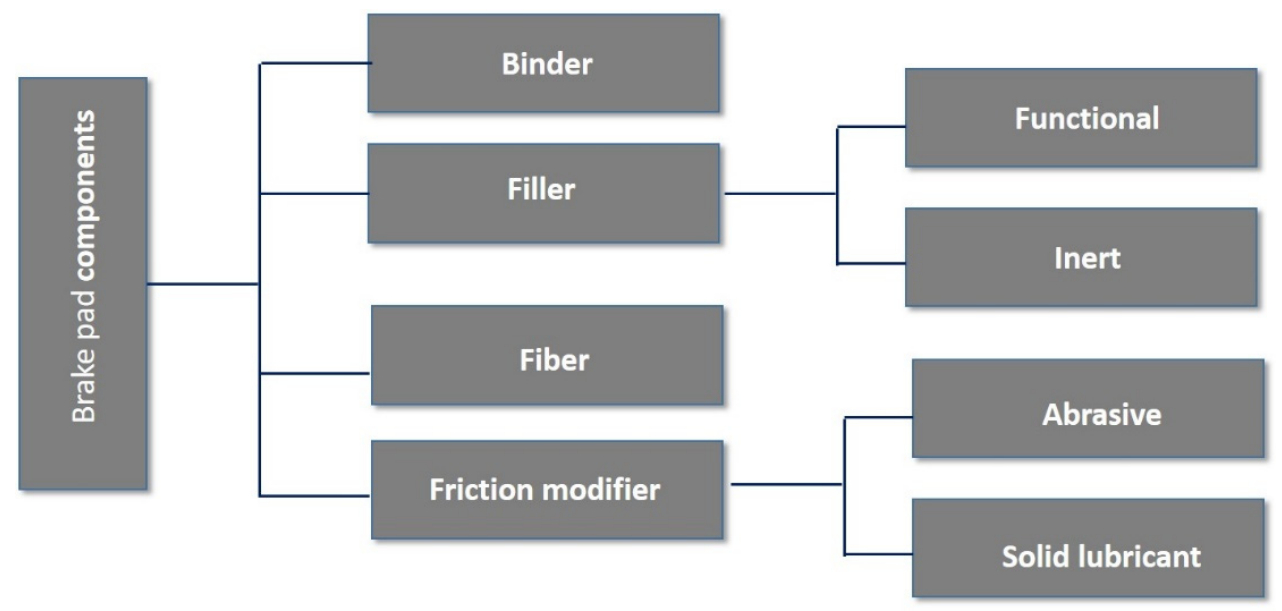

Figure 4. Friction material constituent classification.

Because of their cheap preparation procedure and good tribological qualities, most friction materials for light and commercial cars include an organic matrix (referred to as organic friction compounds). Organic friction materials belong to three groups, according to the different quantities of components [47]: low metallic (LM), semimetallic (SM) and 
nonasbestos organic (NAO) friction materials [48]. Each group consists of many different formulations designed to match the requirements for specific brakes and vehicles.

Selection of the proper constituents and their combination is very problematic and fundamental because of the several requirements to be fulfilled by them [49]. A brief description of the different components of friction materials is provided in Table 2.

Table 2. Main components and main characteristics of friction materials [50-52].

\begin{tabular}{|c|c|c|}
\hline $\begin{array}{l}\text { Friction Materials } \\
\text { Typologies }\end{array}$ & Common Content & Main Characteristics \\
\hline $\begin{array}{l}\text { Low } \\
\text { metallic }\end{array}$ & $\begin{array}{c}\text { Fe }(10-50 \%) \text {, steel, copper and copper alloys } \\
\text { and different abrasives }\end{array}$ & $\begin{array}{ll}\text { - } & \text { Medium/high friction coefficient } \\
\text { - } & \text { High friction materials/ rotor wear } \\
\text { - } & \text { At elevated temperature, shows good braking capacity } \\
\text { - } & \text { Good fade }\end{array}$ \\
\hline Semimetallic & $\begin{array}{l}\text { More than } 50 \% \text { Fe and steel fiber and alloy, } \\
\text { porous iron powder, abrasives and } \\
\text { graphite/coke lubricants }\end{array}$ & $\begin{array}{ll}\text { - } & \text { Low / medium friction coefficient } \\
\text { - } & \text { At low temperatures, the wear rate is low } \\
\text { - } & \text { Good wear under heavy loads }\end{array}$ \\
\hline NAO & $\begin{array}{l}\text { 50\% metallic components, friction dust, } \\
\text { phenolic resin, graphite and other } \\
\text { reinforcements }\end{array}$ & $\begin{array}{l}\text { - } \quad \text { Low to medium-high friction coefficient } \\
\text { - } \quad \text { Excellent wear at lower temps, }<200{ }^{\circ} \mathrm{C}\end{array}$ \\
\hline
\end{tabular}

Basically, the friction material manufacturing process is divided into different steps as reported in Figure 5.

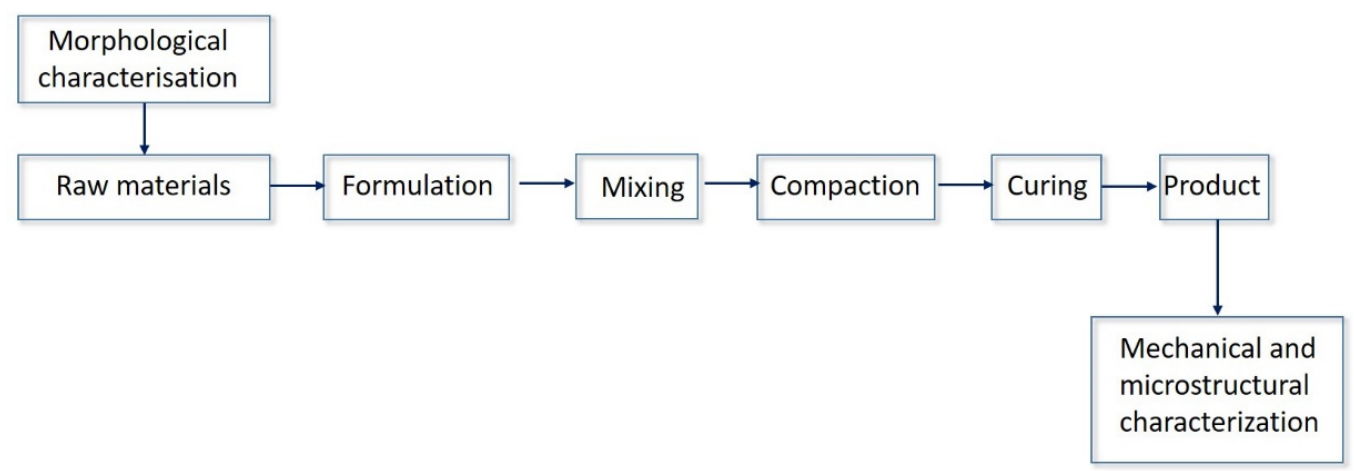

Figure 5. Brake pad manufacturing process.

Constituents are appropriately homogenized in a blend during the compression molding procedure. The molding and preliminary curing of the composite under heat and pressure is an essential phase in the production of friction materials. In most cases, the molding process is pressing a homogenous mixture of components into a shaped mold at $150-200{ }^{\circ} \mathrm{C}$ under pressure ranging from 30 to $70 \mathrm{MPa}$. Molding pressure, duration and temperature must be carefully set to fit the material formulation [53].

\subsection{Binder}

The role of the binder is to keep friction material components all together, guaranteeing their structural integrity under mechanical and thermal stresses without sacrificing other significant properties. The binder choice depends on the required performance of the brake pad, which in turn depends on the preparation process. The typical percentage of the binder in the friction material ranges between 20 and $40 \%$. One of the most used binders is phenolic resin, or modified phenolic resin, formed by a condensation reaction between phenol and formaldehyde [54]. They are usually mixed with various rubbers [55]. Because of their affordability; high specific strength; good mix of thermal, mechanical and tribological qualities and ease of handling, phenolic resins have been almost universally employed as binders in friction materials for decades [56], notably after patents [57]. 
However, phenolic resins are sensitive to high temperature and humidity. The temperature reached during high-energy braking stress or an emergency stop can be high enough to degrade the resin. Above $450{ }^{\circ} \mathrm{C}$, temperature of carbonization of phenolic resins, the decomposition process starts, decreasing the density of the friction material by increasing the porosity. This phenomenon can reduce structural integrity, resulting in a reduction in the friction coefficient, excessive wear and the release of noxious volatiles $\left(\mathrm{NH}_{3}\right.$ and $\mathrm{HCHO}$ [ [58]. Lower temperatures $\left(300-400{ }^{\circ} \mathrm{C}\right)$ can also result in serious concerns: when the resin glass transition temperature is exceeded, fade can occur, inducing a reduction in braking efficacy [50,59]. In order to obtain stable performance at high temperatures, phenolic resins are modified with a variety of compounds/processes to obtain, among others, condensed polynuclear aromatic (COPNA) resins, silicone-modified resins, cyanate ester resins, epoxy-modified resins, cashew-nut-shell-liquid (CNSL)-modified resins and rubber modified resins [44]. Bijwe et al. studied the properties of (i) straight phenolic resin, (ii) CNSL-modified resin, (iii) alkylbenzene-modified resin, (iv) NBR-modified resin and (v) linseed-oil-modified resin, finding that alkylbenzene-modified resin composites achieved the best performance in terms of strength, friction, fade and recovery, although wear resistance was low. Linseed-oil-based phenolic resin composites showed, instead, the opposite behavior [59]. Jang et al. (2000) investigated six different brake friction materials in terms of friction and wear behavior. Five constituents were used: phenolic resin (unmodified and modified resins in powder forms), aramid pulp, potassium titanate, barite and graphite. They found a good thermal stability for friction materials containing the modified resin. Furthermore, aramid-pulp-reinforced components had better friction stability than nonaramid-pulp-reinforced components. During the drag test, the wear rate was dependent on the friction level, porosity, heat resistance and mechanical strength of the binder resin [60]. Polybenzoxazine, a thermoset polymer, with mechanical, thermal and flame retarding properties similar to phenolic resin, was studied as possible friction material by Zeng at al. The addition of phenolic resin and rubber decreased the curing temperature and increased the glass transition temperature of polybenzoxazine resin. When braking temperatures were increased to 200 or $250{ }^{\circ} \mathrm{C}$, there was a considerable rise in friction coefficients and wear rate values for all composites. As for polybenzoxazine, at $100{ }^{\circ} \mathrm{C}$, the lowest friction coefficient was observed, while at $350{ }^{\circ} \mathrm{C}$, the highest friction coefficient was observed. Concerning wear results, polybenzoxazine exhibited the lowest wear rate at $350^{\circ} \mathrm{C}$ [61]. Although several works focused on a possible green alternative, phenolic/phenol-formaldehyde resin still remains the most studied and used.

\subsection{Fiber}

Fiber's role is to increase friction materials' mechanical properties and provide high thermal stability and structural integrity as well as adequate frictional value and stability. Fiber should also reduce shear and thermal stress, which can affect thermal fade and friction instability $[31,62]$. Fiber concentration and dimension are important for a good interaction with the matrix, since the lack of interfacial bonding between the constituent and the matrix can result in excessive wear. Fiber orientation also plays an important role, affecting wear resistance.

After the ban of asbestos, several types of other fibers were added to friction materials and their mechanical properties have been widely investigated. Commonly, commercial friction materials contain 5-25\% $(v / v)$ fiber ingredients [63] belonging to all the different materials classes (metallic, organic and inorganic) [64]. Addition of organic-inorganic and inorganic-inorganic fiber combinations appeared the most significant in enhancing various characteristics of brake friction materials [65]. Qu et al. studied the effect of steel fiber orientation with respect to sliding direction on frictional properties, observing a better wear resistance and a fair friction coefficient when parallel fibers were employed [66]. As for the fiber dimension, Oztürk et al. investigated the effects of resin type (phenolic resin, cashew-nut-shell-liquid-modified resin and melamine resin) and lapinus fiber length $(150 \pm 25,300 \pm 50$ and $650 \pm 150 \mu \mathrm{m})$ on mechanical and tribological properties. The 
authors found a positive correlation between the fiber length and the wear resistance of the composites. Furthermore, the friction coefficient was strongly correlated with the composites' wear resistance [67]. Table 3 shows the main fibers utilized in friction materials and their principal features.

A mix of two or more different types of fibers is normally used, with the purpose of endowing friction materials with lower cost and higher mechanical and physical properties [68]. Using aramid pulps and potassium titanate whiskers as reinforcing fibers, for example, a synergistic behavior in wear resistance and friction stability was found [63]. Due to the carcinogenicity of titanate whiskers, granular and platelet shapes were also studied as potential substitutes, considering both potassium and potassium $/ \mathrm{magnesium}$ as cations. Platelets of magnesium/potassium titanates were found promising as reinforcing materials, behaving as mild solid lubricants and increasing the hardness of the organic matrix [69].

Patnaik et al. measured the physical, mechanical and tribological properties of friction materials made of a ternary mix including potassium titanate whiskers, aluminosilicate ceramic fibers, and aramid fibers. Composites with higher content of ceramic whisker fiber (13.75\% weight each) in conjunction with less aramid fiber $(2.5 \mathrm{wt} \%)$ had promising friction coefficients and considerably lower fading propensities [70].

Wollastonite, a natural mineral, was used in the form of powder and fiber as a potential asbestos substitute, and a good performance in terms of wear and friction fluctuation was observed [71].

Because of their unique features and functions, such as friction stability, wear resistance, heat dissipation and noise dampening, copper and copper alloys have been widely employed as fiber materials. Moreover, copper has a fundamental role in friction materials since it helps in nanocrystalline tribofilm formation, which is responsible for smooth sliding conditions [32]. The need of substituting copper fibers due to environmental regulations has prompted efforts in finding alternative materials. Aranganathan and Bijwe, who categorized copper as a filler, substituted it with a patented special-grade graphite (C-Therm 011) in brake friction material formulation. An increase in thermal conductivity with increased graphite weight percentage was observed [72].

Table 3. Principal fibers employed in friction materials.

\begin{tabular}{|c|c|c|c|}
\hline Fibrous Material & & Advantage & Drawback \\
\hline \multirow{3}{*}{ Metallic } & Steel & $\begin{array}{l}\text { - } \quad \text { Gives good wear resistance } \\
\text { - } \quad \text { Maintains friction effectiveness at high } \\
\text { temperatures (fade resistance with fast } \\
\text { recovery) [73]. }\end{array}$ & $\begin{array}{l}\text { - } \quad \text { Excessive brake disc/brake } \\
\text { wear is possible [73] }\end{array}$ \\
\hline & $\begin{array}{l}\text { Copper and copper } \\
\text { alloy }\end{array}$ & $\begin{array}{ll}\text { - } & \text { Supports the level of the (COF) at } \\
\text { elevated temperatures } \\
\text { - } & \text { High thermal conductivity } \\
\text { - } & \text { Stability in friction, i.e., a low } \\
\text { sensibility of friction towards pressure } \\
\text { and speed [74] }\end{array}$ & - $\quad$ High environmental impact \\
\hline & Brass & $\begin{array}{ll}- & \text { Good plasticity } \\
\text { - } & \text { Enhances heat dissipation [50] }\end{array}$ & - $\quad$ Poor wear performance [50] \\
\hline Organic & Kevlar & $\begin{array}{ll}\text { - } & \text { Good stiffness } \\
\text { - } & \text { High thermal stability, regular friction } \\
& \text { force and wear resistance [75] }\end{array}$ & $\begin{array}{ll}- & \text { High cost } \\
- & \text { COF reduction }\end{array}$ \\
\hline
\end{tabular}


Table 3. Cont.

\begin{tabular}{|c|c|c|c|}
\hline Fibrous Material & & Advantage & Drawback \\
\hline \multirow{4}{*}{ Inorganic } & Wollastonite & $\begin{array}{ll}\text { - } & \text { High thermal resilience } \\
\text { - } & \text { Stabilizes friction coefficient [76] }\end{array}$ & - Weak toxic [77] \\
\hline & Potassium titanate & $\begin{array}{l}\text { Thermal stability at elevated } \\
\text { temperatures due to higher melting } \\
\text { point }\left(1250-1310^{\circ} \mathrm{C}\right)[63]\end{array}$ & $\begin{array}{l}\text { - Acicular whiskers could be } \\
\text { classified as carcinogens [30] }\end{array}$ \\
\hline & Glass & $\begin{array}{ll}\text { - } & \text { Excellent heat and impact resistance } \\
\text { - } & \text { High melting point [78] }\end{array}$ & $\begin{array}{ll}- & \text { Noise generation } \\
\text { - } & \text { Brittleness } \\
\text { - } & \text { Can cause for excessive wear of } \\
& \text { friction materials [50] }\end{array}$ \\
\hline & Carbon fiber & $\begin{array}{ll}\text { - } & \text { High strength } \\
- & \text { High elastic modulus } \\
- & \text { Stable chemical properties and } \\
& \text { resistance to carbonization [79] }\end{array}$ & - $\quad$ Costly [80] \\
\hline
\end{tabular}

\subsection{Friction Modifiers}

Friction modifiers are employed for inducing the proper friction coefficient and wear resistance. They are classified as abrasives and solid lubricants. The former improves wear resistance of friction material and increases the friction coefficient, while the latter reduces the friction coefficient level and stabilizes it over a wide range of temperatures, forming a friction film at the pad-disc interface. Lubricants can also protect the rotor surface by producing a thin coating at high temperatures, reducing noise and vibrations.

Abrasive particles, along with solid lubricants, play a crucial role in brake performance. Indeed, the lubricant and abrasive amount are factors of paramount importance: a high lubricant quantity can weaken the composite, whereas an excess of abrasives may provoke abrasion (two-body and three-body), causing high friction coefficient variation. Usually, the amount of abrasives is up to 10\%, while that of lubricants ranges between 5 and 29\% [81].

Abrasives in commercial friction materials are hard particles which usually have a Mohs hardness ranging from 5 to 9 , and the most commonly used are reported in Table 4 .

Table 4. Principal friction modifiers employed in friction materials.

\begin{tabular}{clc}
\hline Abrasive & $\begin{array}{l}\text { Zircon, zirconium silicate, quartz, alumina, zirconia, silicon carbide, } \\
\text { chromium oxide, silica, mullite. }\end{array}$ & [82-85] \\
\hline Lubricant & $\begin{array}{l}\text { Antimony trisulphide, graphite, molybdenum disulphide, tin } \\
\text { sulphide, petroleum coke, lead sulphide. }\end{array}$ & {$[86,87]$} \\
\hline
\end{tabular}

The abrasive choice depends on the other constituents and on the type of friction materials. They are selected based on shape, size, hardness and fracture toughness. Wear resistance and aggression against counter discs are other significant attributes [88]. Quartz and its polymorphs were generally used in friction materials as abrasives, but their use was limited because crystalline silica, inhaled in the form of quartz or cristobalite from occupational sources, was classified as carcinogenic to humans (Group 1) by the IARC [89]. Moreover, the IARC classified $\mathrm{SiC}$ in the form of fiber as a potentially cancerogenic material [90].

Lubricants protect the components from wear, creating a friction layer and providing a stable friction coefficient for a wide range of environmental conditions and stress conditions. Furthermore, lubricants must decrease noise and vibration at the friction contact caused by stick-slip. Because each lubricant has a distinct working temperature, friction materials frequently incorporate two or more solid lubricants to ensure friction stability across a broad temperature range [86].

The most extensively used solid lubricant is graphite, which is able to build a lubricant layer on the counterface, significantly reducing the friction coefficient. Kchaou et al. studied 
the effect of graphite forms (thermally pure vein graphite, thermally pure flake graphite and purified expandable graphite) on friction material performance. The use of an expandable graphite composite resulted in enhanced thermal stability, superior fade resistance and decreased wear rate [91]. The lubricant effect of graphite and, in general, of carbon-based materials, was found to be affected by particle size, shape and density. Indeed, a study on six carbon materials, four of which consisted of graphite, showed that the lower the size and aspect ratio, the lower the friction coefficient. High density resulted in a stable and homogeneous tribolayer at the interface, reducing the COF. Finally, the graphite structure also played an important role: indeed, a higher number of overlapped aromatic planes appeared more prone to produce a thick and stable tribofilm, lowering the COF [48]. Rajan et al. compared tribological performance of graphene in phenolic-based friction composite with a sample filled with graphite. Results indicated that graphene gives high friction stability, friction-fade and friction-recovery performance [92].

Antimony oxide $\left(\mathrm{Sb}_{2} \mathrm{O}_{3}\right)$ and stibnite $\left(\mathrm{Sb}_{2} \mathrm{~S}_{3}\right)$, both of which rapidly degrade to stable oxide forms during brake wear, are also utilized as lubricants in friction materials. Though antimony is considered a potential cancerogenic element, few alternatives can be found in literature. Tin sulphides are the most promising candidates for antimony substitution in friction material composition [93]. The effects of zirconium silicate $\left(\mathrm{ZrSiO}_{4}\right)$ and antimony trisulphide on the friction characteristics were investigated, finding that $\mathrm{Sb}_{2} \mathrm{~S}_{3}$ improved the friction stability and $\mathrm{ZrSiO}_{4}$ intensified the torque variation during brake applications [83].

\subsection{Filler}

Fillers are defined as materials with a minimum impact on friction performance. Two categories of fillers are used: inert and functional. The first is used to merely fill space and to lower manufacturing and product costs. The second type is principally used for a precise purpose, such as thermal resistance or to achieve homogeneous mixing. In terms of composition, fillers are subdivided into organic and inorganic. The type of friction material to be utilized as well as the other ingredients determine the filler to be used. Table 5 summarizes the principal organic and inorganic fillers.

Table 5. Main fillers used as constituents of friction materials.

\begin{tabular}{|c|c|c|c|}
\hline Name & $\begin{array}{c}\text { Role } \\
\text { (Space/Functional) }\end{array}$ & Advantages & Drawback \\
\hline \multicolumn{4}{|l|}{ INORGANIC } \\
\hline Vermiculite & Functional & $\begin{array}{ll}- & \text { Low density } \\
\text { - } & \text { Low hardness } \\
\text { - } & \text { Good thermal stability }[94,95]\end{array}$ & $\begin{array}{l}\text { - Low heat resistance } \\
\text { (except when exfoliated) }\end{array}$ \\
\hline Barium sulphate & Space & $\begin{array}{ll}- & \text { Heat stability } \\
- & \text { Reduction in material cost [96] }\end{array}$ & $\begin{array}{ll} & \text { Large frictional } \\
\text { oscillations [95] }\end{array}$ \\
\hline Mica & Functional & - $\quad$ Noise suppressors [97] & - \\
\hline Molybdenum trioxide & Functional & $\begin{array}{ll} & \text { Suppresses low-frequency brake noise } \\
\text { - } & \text { Gives heat stability for the material [98] }\end{array}$ & - \\
\hline Calcium carbonate & Space & - $\quad$ Low density [50] & - \\
\hline $\begin{array}{l}\text { Hexagonal boron } \\
\text { nitride }(\mathrm{h}-\mathrm{BN})\end{array}$ & Functional & $\begin{array}{l}\text { - } \quad \text { At high temperatures, it is chemically } \\
\text { and thermally stable } \\
\text { - } \quad \text { High thermal conductivity [99]. }\end{array}$ & - \\
\hline \multicolumn{4}{|l|}{ ORGANIC } \\
\hline Cashew friction dust & Functional & $\begin{array}{ll}- & \text { Reduces fluctuations in friction } \\
\text { coefficients [100] }\end{array}$ & - \\
\hline Rubber & Functional & $\begin{array}{l}\text { - Superior viscoelastic characteristics and } \\
\text { brake noise reduction [101] }\end{array}$ & $\begin{array}{l}\text { - } \text { Affected by the } \\
\text { vulcanization process } \\
\text { [102] }\end{array}$ \\
\hline
\end{tabular}




\subsubsection{Inorganic Filler}

Vermiculite is made up of two silica tetrahedral sheets and has a lamellar structure. Due to its weak cohesive force between interlayers, homogeneous mixing is achieved [95]. Vermiculite can be exfoliated when heated rapidly to high temperatures. When exfoliated, vermiculite, a mineral filler with a stacked-layer morphology, can be utilized up to $30-50 \mathrm{wt} \%$ in friction composites and is known to improve friction material stability, durability and resilience to high temperatures [103,104].

Barium sulphate, considered a low-cost and nonhazardous raw material, turns into barium sulphide due to a reaction between carbon from phenolic resin with the formation of carbon dioxide. Kumar claimed that barium sulphide fills brake disc interstitial voids and creates a film on the disc surface, protecting the rotor surface from wear [50].

Calcium carbonate is a less expensive alternative to barium sulphate.

Mica is another frequent filler. Indeed, due to its plane-net-shape structure, it can suppress low-frequency noise. Nevertheless, because of low interlayer strength, mica can provoke friction materials' interlayer splitting [54].

Calcium sulphate $\left(\mathrm{CaSO}_{4}\right)$ whiskers can be also used as fillers due to their highly ordered crystal structure, endowing $\mathrm{CaSO}_{4}$ with high thermal stability.Less wear was detected using $\mathrm{CaSO}_{4}$ whiskers as a functional filler and a composite, with $10 \% \mathrm{CaSO}_{4}$ whiskers displaying the most stable COF, even at high sliding speeds [105].

Kosbe et al. studied the physical properties and friction performance of friction materials' varying weight percentages of hexagonal boron nitride (h-BN) as a functional filler while the $\mathrm{wt} \%$ of barite was decreasing. Results showed an enhanced thermal conductivity from $0.86 \mathrm{~W} / \mathrm{mK}$ to $1.40 \mathrm{~W} / \mathrm{mK}$ with an increasing h-BN percentage. Furthermore, the composite with the most h-BN content showed the lowest friction fluctuations and a high coefficient of friction [99].

Many other fillers are incorporated into friction materials, such as alkali metal titanates, commonly used to stabilize the friction coefficient.

\subsubsection{Organic Filler}

Rubber is a common ingredient for friction materials. Among different rubbers, nitrile butadiene (NBR), a copolymer of synthetic rubber based on acrylonitrile (ACN) and butadiene, is used because of excellent chemical stability and vibration absorption [106]. The vulcanization process, which is commonly performed using sulphur- or peroxidebased solutions, is responsible for the majority of the physical qualities of rubber [107]. The principal role of rubber is the reduction in brake noises because of its superior viscoelastic characteristics.

Cashew dust, a substance formed by polymerizing cashew nut shell liquid with a curing agent, is also used for the same reason [108].

\section{Green Constituents as Alternatives for Friction Materials}

Over the years, many changes in the ingredients of friction material formulation have occurred. These changes arise from two major factors: improvement in brake performance and the need to meet legal requirements for environmental protection. In order to explore research trends on the study of constituent substitution for reducing environmental impact, a science mapping analysis was conducted.

The study was conducted using VOSviewer software version 1.6.16, consulting the SCOPUS database from the years 1980, the date of the asbestos ban, to 2021, using as a search option "all fields" with the following word combinations (the number of found publications is reported inside brackets): "brake pad (friction materials)" - "eco-friendly" (329); "brake pad (friction materials)" — "natural fiber" (316); "brake pads (friction materials)" - "green material" (33); "brake pads (friction materials)" - "agricultural waste" (50). Figure 6 reports a mapping visualization of the research of publications of "brake pad (friction materials)" "natural fiber". The following parameters were used to create the map: minimum numbers of occurrence keywords: 10; clustering resolution: 1. 


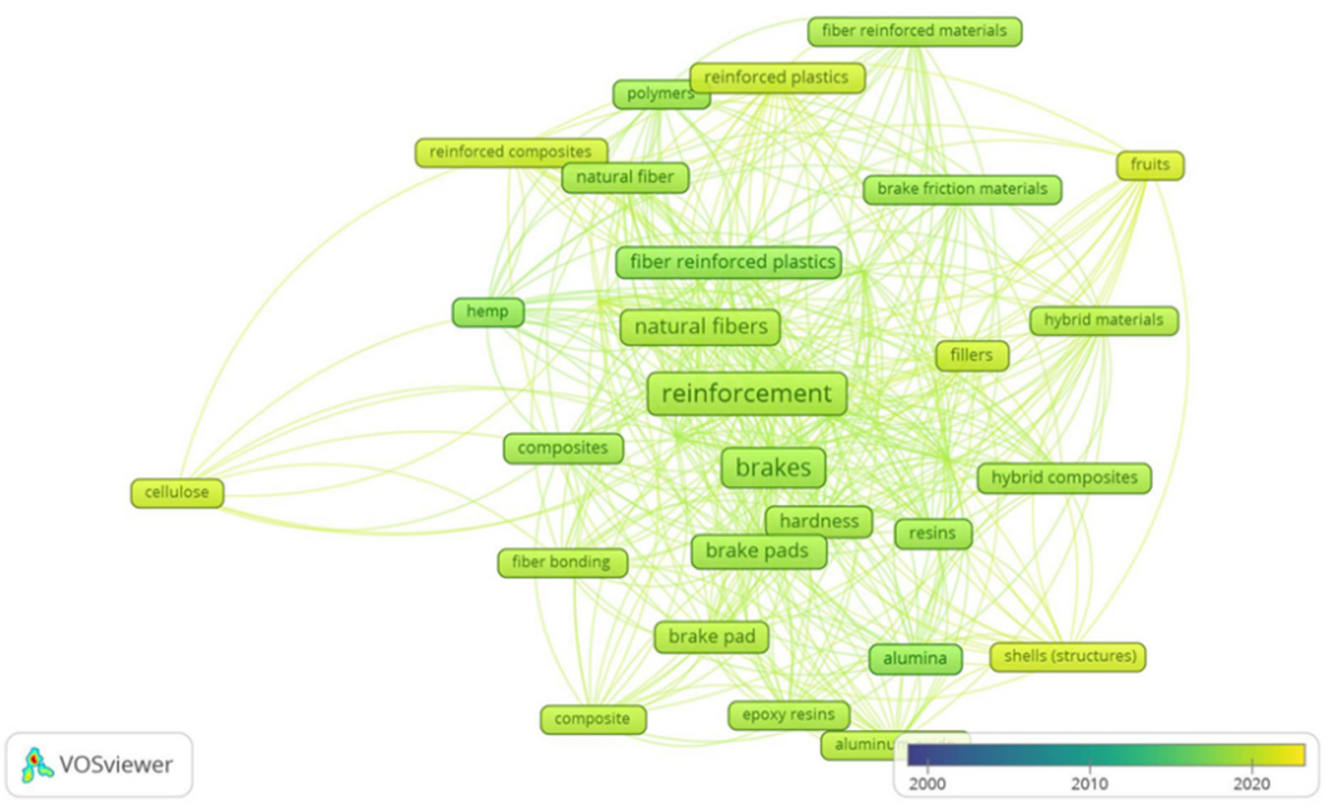

Figure 6. Representation of the relations between different keywords emerging from the analysis of the terms "brake pad (friction materials)" and "natural fiber".

The VOSviewer results showed 2249 keywords. In order to make the connections clearer, the terms related to friction material characterization, for example, friction, wear and scanning electron microscopy, were eliminated and only the terms related to materials and friction materials were considered.

Each frame, marked with a different color, represents a term, whose size (diameter) indicates the number of publications where the term (title, abstract or keyword) occurred. The greater the frame, the higher the frequency of that keyword in the sample.

Furthermore, the closer the frames are to each other, the more often the terms occurred together, and the thicker the line connecting them, the more significant the co-occurrence.

Based on Figure 6, the most frequent keywords that occurred were "reinforcement" and, obviously, "friction materials (brake pads)". Among the alternative materials, "natural fiber" showed the highest occurrence (67), while materials such as "cellulose" (11), "fruits" (10) and "hemp" (13) had a much lower occurrence.

Even though the analysis spanned the period 1980-2021, Figure 6 shows the trend from 2000 to present because in the previous period, very few works on this subject were found. It can be noticed that most of the works concerning natural fibers were published after 2010 and those related to cellulose and hemp are even more recent.

\subsection{Green Binders}

Few papers reporting about green or ecofriendly binders are present in literature. This fact can be related to the difficulties in finding good alternatives to phenolic resin in terms of mechanical and tribological properties.

Pizzi et al. (2016) studied the possibility of preparing friction materials using bio-based resin composed of tannins-furanic resin embedding inorganic abrasive particles. This green alternative showed excellent braking performance, comparable with commercial friction materials [109].

In the last decades of the 20th century, lignin was considered a promising alternative for phenol in phenol-formaldehyde (PF) resin synthesis, due to its structural similarity with PF.

Lignin is an integral part of the secondary cell walls of plants. Depending on wood type, isolation method and plant source, lignin structure can vary. Due to its properties, high amounts of lignin in wood can provide raw material with good durability [110]. Nehez (1997) proposed to apply organosolv lignin to friction materials in order to partially reduce 
the amount of phenolic resins [111]. A friction material with a lignin-phenol resin as a binder was patented in 2012 [112].

Three different types of lignin (soda lignin and sulphuric acid lignin-SAL and heattreated) were studied, using cashew nut shell liquid as a filler [113]. Moreover, lignin was also used as a filler in association with phenol-formaldehyde resin as a binder. When lignin was applied as a binder, only soda lignin showed a moderate advantage in terms of enhancing impact strength and regulating the friction coefficient. Instead, when lignin was used as a filler, heat-treated SAL lignin showed the best properties. The most suitable composition was with $10 \%$ lignin in the friction materials. Figure 7 shows friction coefficients, wear resistance, impact strength and thickness swelling in water of friction materials with lignin added as a binder [113].

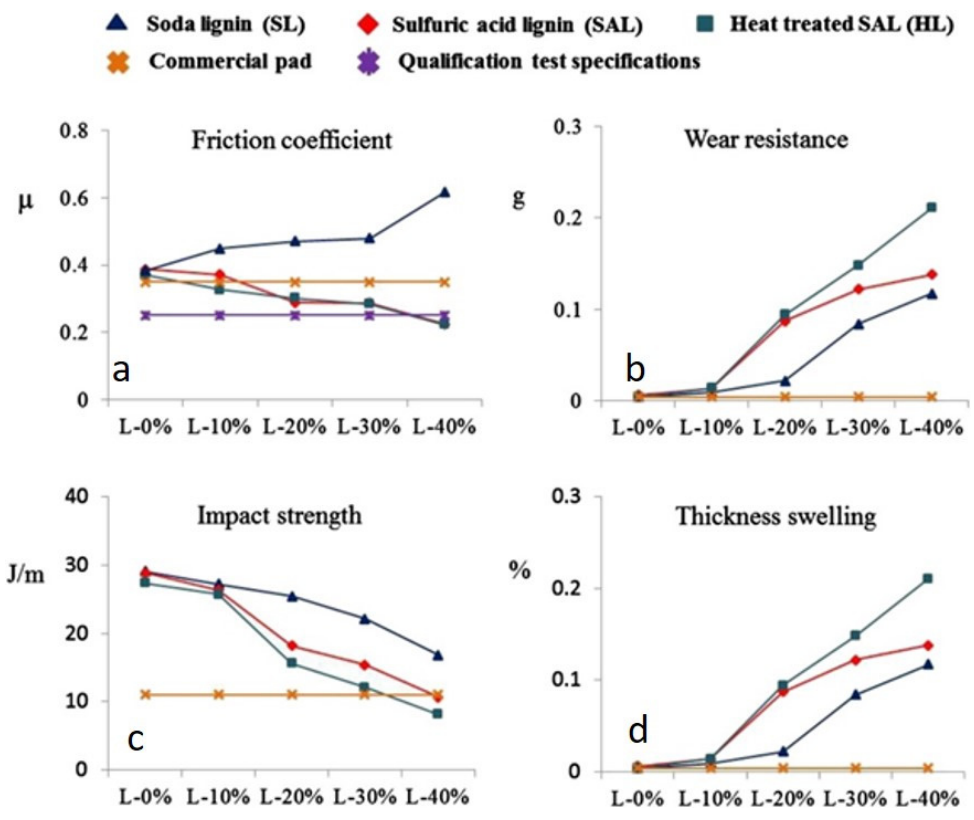

Figure 7. The effect of friction materials containing different amounts of lignin as a binder on: (a) friction coefficient, (b) wear resistance, (c) impact strength and (d) thickness swelling in water (courtesy of Park et al. [113]).

Another material that has showed interesting properties to potentially substitute nongreen binders is geopolymer. This inorganic compound has a chemical composition quite similar to zeolite, with an amount of amorphous content depending on precursor and synthesis conditions. The mechanical properties of the geopolymers are similar to those of cements and organic resins and they have a higher heat resistance than organic binders. Lee et al. investigated the wear and friction performance of a composite consisting of an environmentally friendly geopolymer and natural hemp fibers as a fraction replacement of phenolic resin and synthetic Kevlar fibers, respectively, with the goal of substituting $\mathrm{Cu}$ and $\mathrm{Sb}$. Dyno analyses revealed a higher friction level of the $\mathrm{Cu}$-free samples compared to the baseline material (formed with $9.5 \mathrm{wt} \%$ phenolic resin, $3.4 \mathrm{wt} \%$ Kevlar fiber, $8.0 \mathrm{wt} \%$ of copper and $3.6 \mathrm{wt} \%$ of antimony trisulfide). Similarly, a higher value was observed in terms of wear resistance for the modified samples. A stable third-body layer was formed on the unmodified composite, while the friction layer for the green formulation was insufficient [114].

It can be thus concluded that, at the moment, green substitutes for phenolic resins show promising results, as proved by literature and industrial patents. As for the last, in 2015, ITT ITALIA SRL, a company specializing in the production of brake pads, patented friction materials using geopolymer as a binder [115]. However, additional research is still needed to achieve a complete substitution of phenolic resins. 


\subsection{Fibers}

Natural fibers are considered a prospective alternative to synthetic fibers in friction materials because of low cost, low environmental impact, full biodegradability, abundance and renewability. Moreover, using natural fiber, lightweight composites can be produced due to their lower density $\left(1.2-1.6 \mathrm{~g} / \mathrm{cm}^{3}\right)$ compared to other materials, e.g., glass fiber $\left(2.4 \mathrm{~g} / \mathrm{cm}^{3}\right)$ [116]. However, even though different natural fibers were tested, most of them presented flaws such as low wettability, lack of integration with certain polymeric matrices and excessive moisture absorption [117]. Moreover, fiber strength, modulus, fiber length, orientation and fiber-matrix interfacial bond strength may influence mechanical properties of composites. A good interfacial bond is required to transmit stress from matrix to fiber. For this reason, chemical treatments are necessary [118], and the most common are utilizing $\mathrm{NaOH}$, benzoyl chloride, silane, $\mathrm{HCl}$, plasma and $\mathrm{KOH}$ [119].

As an example, Figure 8 shows the effect of the chemical treatments $(\mathrm{NaOH}$-treated fiber and $\mathrm{NaOH}+$-acrylic-acid-treated fiber) on bagasse fiber. It was found that both chemical treatments destroyed the cellular structure of the bagasse fiber, reducing its void content [120].
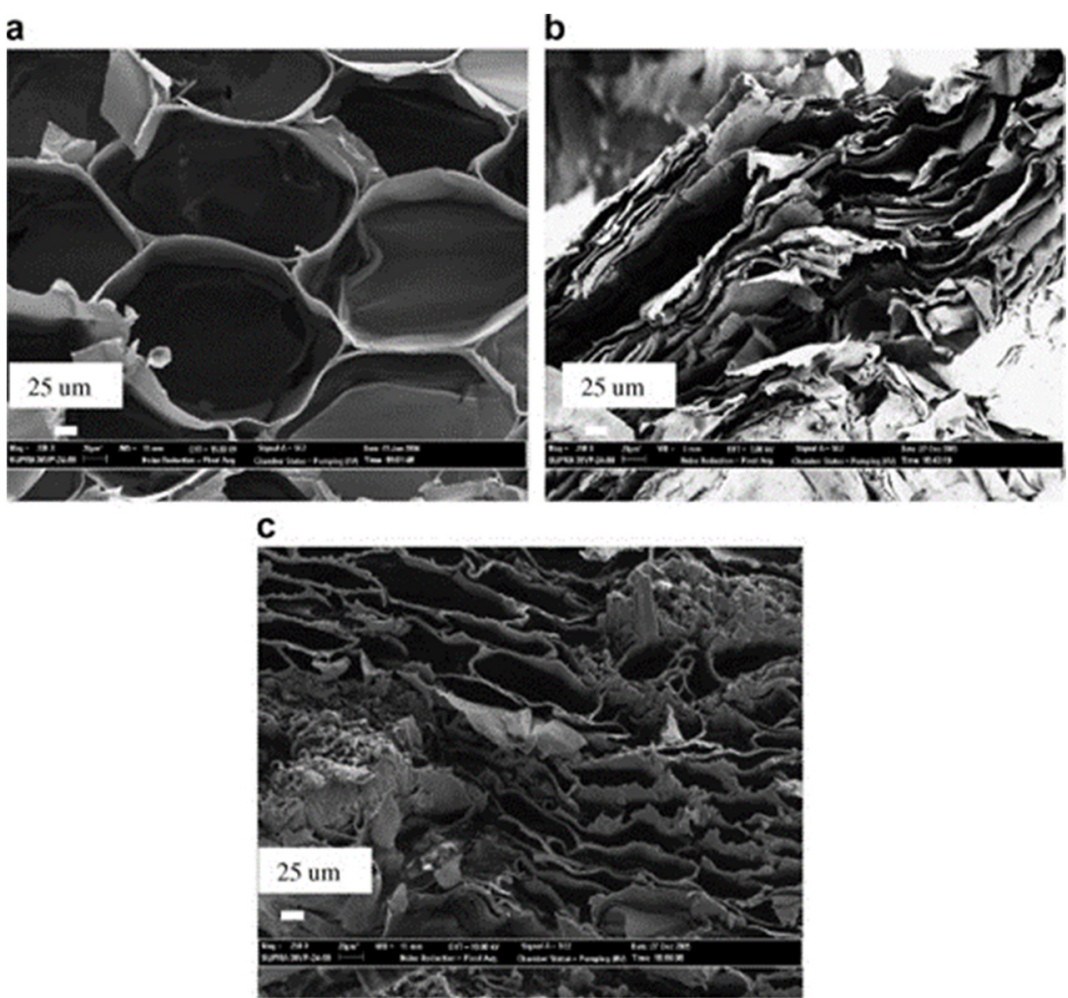

Figure 8. Effect of the fiber treatment on the structure of bagasse fibers: (a) bare bagasse fiber, (b) $\mathrm{NaOH}$-treated fiber and (c) $\mathrm{NaOH}+$-acrylic-acid-treated bagasse fiber (courtesy of Vilay et al. [120]).

Another crucial aspect that can influence natural fiber properties is thermal stability. Indeed, degradation of natural fibers leads to a deterioration of their mechanical properties. Fibers show different temperatures of decomposition. For example, sisal thermal degradation range temperature is between 290 and $490^{\circ} \mathrm{C}$, kenaf fibers degrade at $297-434^{\circ} \mathrm{C}$, while bamboo fibers degrade at $250-420{ }^{\circ} \mathrm{C}$ [121-123]. Table 6 highlights mechanical properties and chemical treatments utilized for fiber optimization. 
Table 6. Mechanical properties and chemical treatments of ecofriendly fibers from plants.

\begin{tabular}{|c|c|c|c|c|c|c|}
\hline Plant & $\begin{array}{l}\text { Elongation } \\
(\%)\end{array}$ & $\begin{array}{l}\text { Density } \\
\left(\mathrm{g} / \mathrm{cm}^{3}\right)\end{array}$ & $\begin{array}{c}\text { Tensile } \\
\text { Strength (MPa) }\end{array}$ & $\begin{array}{c}\text { Tensile } \\
\text { Modulus (GPa) }\end{array}$ & $\begin{array}{c}\text { Most Used } \\
\text { Chemical Treatment }\end{array}$ & References \\
\hline Sugar palm & 12.8 & 1.48 & 276 & 3.85 & Alkaline treatment & [124] \\
\hline Palm kernel & - & - & - & - & Sodium hydroxide & [125] \\
\hline Areca & $1.47-1.48$ & $1.05-1.25$ & 35.68 & - & Alkaline treatment & {$[118,126,127]$} \\
\hline Banana & 10.35 & 1.35 & $529-914$ & - & Alkaline & [128-131] \\
\hline Bagasse & 1 & 1.3 & $222-290$ & - & Alkaline + Acrylic acid (AA) & {$[120,132,133]$} \\
\hline Corn stalks & $1.90-2.30$ & $0.21-0.38$ & $33.40-34.80$ & - & Alkaline treatment & {$[134,135]$} \\
\hline Jute & $1.5-1.8$ & 1.3 & $393-773$ & $10-30$ & $\begin{array}{c}\text { Alkaline }+\mathrm{HCl} \\
\mathrm{HCHO} \text { and } \mathrm{C}_{6} \mathrm{H}_{6}+\mathrm{NaOH}+\mathrm{H}_{2} \mathrm{SO}_{4}\end{array}$ & {$[133,136,137]$} \\
\hline Bamboo & 1.4 & 1.1 & 500 & & Alkaline & [136] \\
\hline Kenaf & $2.5-3.5$ & 1.2 & $223-930$ & 40 & Alkaline & {$[138,139]$} \\
\hline Abaca & 2.9 & 1.5 & $430-813$ & & $\mathrm{NaOH}+\mathrm{H}_{2} \mathrm{SO}_{4}$ & {$[131,140]$} \\
\hline Flax & $2.7-3.2$ & 1.5 & $345-1035$ & & $\mathrm{NaOH}+\mathrm{HCl}$ & {$[131,136,141,142]$} \\
\hline Coconut & $15-51.4$ & $1.15-1.46$ & 95-230 & - & - & [133] \\
\hline Pineapple & 14.5 & $0.8-1.6$ & $400-627$ & & Alkaline & {$[143,144]$} \\
\hline Sisal & $2.0-7.0$ & $1.33-1.5$ & $363-700$ & $9.8-38$ & $\begin{array}{c}\mathrm{NaOH}-\mathrm{Ammonia} \text { base liquor+ } \\
\mathrm{H}_{2} \mathrm{SiO}_{3}, \mathrm{Na}_{2} \mathrm{~B}_{4} \mathrm{O}_{7}-\mathrm{HCHO}-\mathrm{NaHSiO}_{3}\end{array}$ & {$[78,139]$} \\
\hline
\end{tabular}

Rashid et al. studied the influence of sugar palm fiber as a reinforcement. Wear and friction tests were conducted on bare, alkali-treated and seawater-treated composites. Fibermatrix interface bonding was enhanced as a consequence of alkali treatment, resulting in a higher wear performance. Reduction in the friction coefficient was also observed. Figure 9 shows specific wear rate (SWR) of bare and treated sugar palm fiber, while Figure 10 represents SEM images of untreated (UT), seawater-treated (ST) and alkali-treated (AT) composites at 30 and $70 \mathrm{~N}$ loads at $2.6 \mathrm{~m} / \mathrm{s}$ sliding speed and $5000 \mathrm{~m}$ sliding distance. SEM micrographs show the good matrix-fiber bonding promoted by alkali treatment, resulting in the observed higher wear resistance [124].

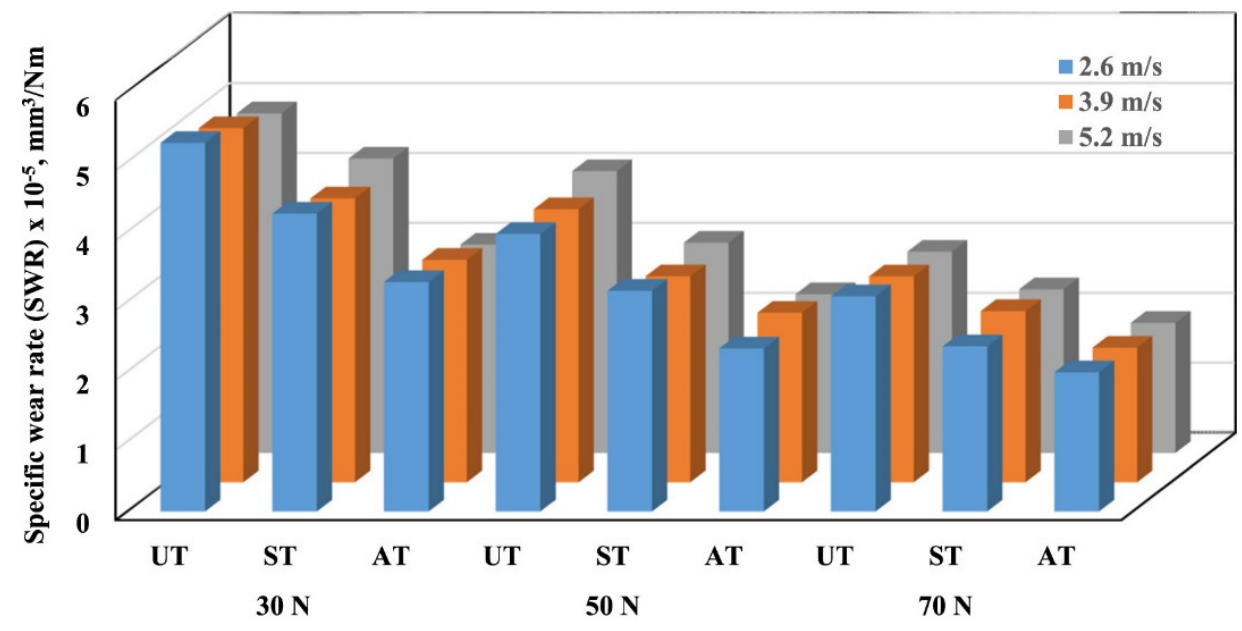

Diffrent applied loads for UT, ST, and AT composites

Figure 9. Specific wear rate (SWR) of bare and treated sugar palm fiber (courtesy of Rashid [124]). 


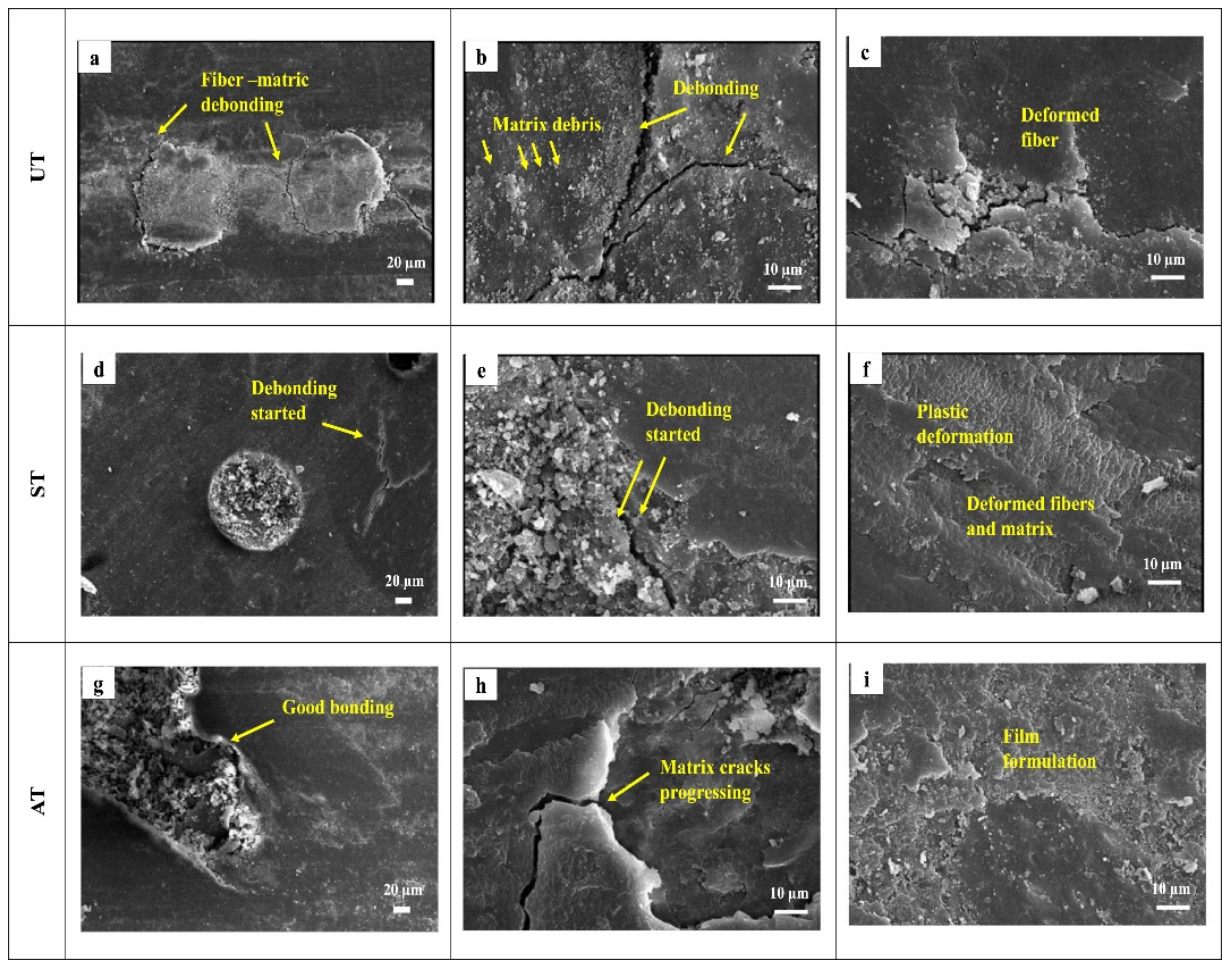

Figure 10. SEM micrographs of (a-c) UT; $(\mathbf{d}-\mathbf{f})$ ST and (g-i) AT composites at 30 and $70 \mathrm{~N}$ loads at $2.6 \mathrm{~m} / \mathrm{s}$ sliding speed and $5000 \mathrm{~m}$ sliding distance (courtesy of Rashid [124]).

Berdard et al. (2018) investigated the impact of palm fiber on the tribological performance of composite materials. It was found that an increase in palm fiber content led to high hardness and $8 \%$ of palm fiber content in friction materials resulted in good tribological performances [145]. Different composites including palm kernel fibers as reinforcement resulted in a hardness decrease with increasing palm fiber content as a consequence of the porosity induced in the composites. Moreover, the palm fiber content decreased the friction coefficient [146].

Palm kernel fibers were also studied by Ikpambese et al. Fibers treated with a caustic soda solution and incorporated in an epoxy resin binder exhibited encouraging results and were considered a viable alternative in friction material manufacturing [125]. A composite incorporating palm kernel shell fibers in epoxy resin using a compression molding technique and adding aluminum oxide, calcium carbonate and carbon showed that with increasing fiber content, hardness and compression strength decreased, probably due to the weak bonding between fiber and resin. In addition, flame resistance dropped as the amount of palm kernel shell fiber increased. However, an increase in wear resistance was observed with increasing fiber content [147].

Other fibers potentially alternative to synthetic fibers are obtained from areca palms and kenaf.

Areca as a friction material constituent was studied by Krishnan et al., who found that a fiber content of $5 \% \mathrm{w} / \mathrm{w}$ was optimal for wear resistance [148].

Employing a weighted decision matrix (WDM) technique, Abdollah et al. investigated the feasibility of using kenaf fiber as a friction material ingredient. The method, which considered the impact on the environment and human health, indicated kenaf fiber as the most suitable material because it passed all the design requirements [149]. However, a friction material made of phenol-formaldehyde resin with three different amounts of kenaf fiber induced decreases in density and hardness when increasing kenaf content [150].

Banana is also considered a valid fiber substitute. Different phenolic resin samples reinforced with lignocellulosic banana fiber at varying resin and banana percentages showed the best tribological results when $7 \%$ of banana fiber and $28 \%$ of phenolic resin were 
mixed [128]. Banana fiber together with coconut fiber, rice husk, graphite powder and aluminum oxide were embedded in epoxy resin, resulting in a wear rate lower than that of common commercial friction materials at a speed of $350 \mathrm{rpm}$ [151]. Aigbodion et al. investigated morphological, physical, mechanical and wear properties of friction materials with uncarbonized and carbonized banana peel particles embedded in phenolic resin. Interestingly, suitable bonding was obtained with uncarbonized banana peel particles. Moreover, after increasing resin quantity, compressive strength, hardness and specific gravity increased, while wear rate decreased [152]. The mechanical and thermal characteristics of banana and ramie fibers treated with $\mathrm{Na}_{2} \mathrm{CO}_{3}$ were the best for a composite reinforced with $10 \%$ banana fiber [153].

Lower wear was achieved using $25 \%$ of candlenut shells and $15 \%$ of coconut shells in friction materials [154].

Among fibers derived from common crops, bagasse provided better properties with finer sieve size and using 30\% bagasse [155].

Friction materials reinforced with corn stalk fiber (CF) embedded in NBR-modified phenolic resin prepared by wet granulation improved tribological and morphological properties, giving the possibility of reducing resin content [156]. Adding corn stalk fibers to friction composites improved the friction coefficients and wear rates [134]. Fu et al. developed an ecofriendly friction material using flax fibers together with mineral basalt and wollastonite as reinforcements embedded in cardanol-based benzoxazine-toughened phenolic resin, with natural graphite as a solid lubricant, zircon as an abrasive and vermiculite and barite as functional and space fillers. Flax fibers helped to stabilize friction coefficients and improve wear rates at high temperatures [142].

Bijwe et al. evaluated the influence of aramid, PAN (poly-acrylo-nitrile), carbon and cellulose on the fade and recovery of friction composites. Higher fade resistance was observed with adding carbon fiber, while composite based on cellulose fiber showed the lowest fade resistance, probably due to its low degradation temperature. Moreover, composites containing aramid and cellulose showed the highest and the lowest wear resistances, respectively [157].

Pineapple fiber, widely used also in different industrial sectors, can be a sustainable alternative for the automotive industry. Friction composites with increasing amounts of pineapple and Kevlar (5-10 wt \%) lowered composite density, hardness and ash content. As for wear behavior, it was observed that increasing the amount of pineapple fibers in the composites increased the specific wear rate, while increasing the amount of Kevlar fibers enhanced it. The introduction of fewer fibers changed the nature of the transfer film and its adhesion to the counterface [143].

Embedding jute fibers with different $(5 \mathrm{~mm}, 10 \mathrm{~mm}, 15 \mathrm{~mm}$ and $20 \mathrm{~mm}$ ) dumbbellshaped spacing in friction materials made of NBR induced strong physical and mechanical properties. Higher fluctuation in friction coefficients was observed using dumbbell-shaped jute fibers compared with straight fibers. As for wear resistance, friction material with dumbbell-shaped spacing of $15 \mathrm{~mm}$ was the highest except at $200-250{ }^{\circ} \mathrm{C}$ [137]. When epoxy composites were reinforced with different percentages of short jute fiber, it was demonstrated that fiber loading, sliding velocity, applied load and abrasive size affected wear rate. Composites with a fiber loading of $36 \mathrm{wt} \%$ displayed the lowest specific wear rate [158].

Lui et al. investigated abaca fibers, which are often used in a variety of applications due to their high tensile strength. Changing the length of an abaca fiber had no effect on density or hardness, but it influenced impact strength. An improvement in wear resistance was obtained with abaca short fibers (lengths of $5 \mathrm{~mm}$ and $10 \mathrm{~mm}$ ) [140].

Both air plasma surface treatment of bamboo fiber and graphite had a positive impact on friction and wear of bamboo/polyimide composites [159].

Due to its good mechanical properties, sisal fiber is commonly used in different fields [116]. Xu et al. (2007) studied the wear and friction parameters of brake composites 
with various sisal fiber contents. The best friction and wear properties were obtained using resin and sisal fiber in the proportion of 3:4 [78].

Microcellulose modified with 3-aminopropyltriethoxy-silane was embedded in phenolic resin together with barium sulphate, aluminum oxide and graphite, with the aim to study mechanical and tribological properties. The researchers discovered that friction material containing $10 \mathrm{wt} \%$ of microcellulose fiber performed similarly to a commercial friction material [160]. Similar tribological behavior was observed when comparing the physical and mechanical performance of cellulose fiber and thermographite and friction material with copper fiber. However, friction material with $\mathrm{Cu}$ exhibited higher thermal stability [161].

Several other natural fibers from uncommon plants have been tested in order to replace synthetic fibers. Krishnan et al. compared friction materials with embedded bare and silanetreated Demostachya bipinnata, a perennial grass, obtaining better tribological results using the treated fiber [162]. Embedded fibers of Cyperus pangorei, a sedge species native to Asia, treated with benzoyl chloride into friction material showed good friction and higher wear resistance with respect to a similar composite containing the untreated fibers [163]. Bajpai et al. incorporated nettle, Grewia optiva and sisal into PLA polymer, which resulted in an improvement of the composite wear resistance [164]. Fibers of Coccinia indica, a tropical vine, embedded in epoxy resin as potential reinforcement for friction materials induced good wear when treated with silane in comparison to sodium hydroxide surface treatments [165]. Akıncıoğlu et al. used boron oxide and hazelnut shell powders as ecofriendly alternatives to chalcopyrite and petroleum coke. Friction materials made of phenol resin with embedded hazelnut shells and boron oxide showed similar hardness with respect to a commercial sample. Moreover, hazelnut dust induced the highest friction coefficient, probably due to the observed enhancement in hardness of friction materials [166].

Because of comparable features, including heat resistance, hardness and good adhesive nature with the binder, basalt was considered as a potential fiber for friction materials. Basalt fibers are made from basalt rocks that have been melted. Basalt rocks can be finely split into little particles to the point where they can be made into fibers [167]. Moses et al. studied physical properties and wear behavior of basalt-fiber-reinforced friction materials, obtaining promising results [168]. Zhao et al. evaluated physicomechanical and tribological performance of the friction composites with different basalt fiber contents. The mechanical and tribological characteristics were enhanced by adding 15\% basalt fiber [169]. The wear mechanism of phenolic resin with embedded flax and basalt fiber was studied using a pin-on-disc wear tester. Higher wear resistance was obtained using $6 \%$ of basalt fiber, probably due to good thermal characteristics and the bonding nature of basalt fibers [170]. When basalt fibers were used with alumina and shellfish powder, hardness of friction materials and wear resistance was higher than that of asbestos-based ones [171].

Grey relational analysis, a system theory based on an orthogonal array, and a fuzzybased Taguchi approach for optimizing the multiresponse process were used to evaluate seashell embedded in epoxy resin with graphite as a friction modifier and aluminum oxide as an abrasive. Results indicated that curing time has a limited effect on the mechanical properties, while it significantly affected friction coefficients and wear rate [172].

Maleque et al. examined five different laboratory formulations made of different coir fiber contents together with silicon carbide as abrasive material, graphite as solid lubricant, zirconium oxide as a friction modifier. Adding $5 \%$ of coir fiber to the mix resulted in increased density, which was seen as encouraging in terms of physical and mechanical qualities [173].

As a result of the increasing drive to reduce environmental impact, some brake pads reinforced with natural fibers have been patented, mainly in China; examples of these are listed in Table 7. 
Table 7. List of some brake pad patents with natural fiber.

\begin{tabular}{clcc}
\hline \multicolumn{1}{c}{ Code } & \multicolumn{1}{c}{ Title } & Inventor & Reference \\
\hline CN103436236A & $\begin{array}{l}\text { Palm-fiber-reinforced environmentally } \\
\text { friendly type brake pad and } \\
\text { preparation method thereof }\end{array}$ & LI MEIFENG & [174] \\
\hline CN103361031A & $\begin{array}{l}\text { Brake pad for flax-fiber-reinforced } \\
\text { environmentally friendly car and } \\
\text { preparation method thereof }\end{array}$ & LI MEIFENG & [175] \\
\hline CN104976258A & Environmentally friendly brake pad & $\begin{array}{l}\text { HUANG } \\
\text { XIAOSHUANG }\end{array}$ & [176] \\
\hline CN103423345A & $\begin{array}{l}\text { Automobile brake pad mixing with } \\
\text { bamboo fibers }\end{array}$ & LI MEIFENG & [177] \\
\hline CN106015400A & $\begin{array}{l}\text { Hibiscus-Manihot-fiber-reinforced } \\
\text { environmentally friendly brake pad } \\
\text { and preparation method thereof }\end{array}$ & JIANG YIKUAN & [178] \\
\hline CN106641049A & $\begin{array}{l}\text { Method for preparing brake pad from } \\
\text { basalt fiber }\end{array}$ & LI XIAOCHUAN & {$[179]$} \\
\hline
\end{tabular}

This literature overview demonstrates the potential of natural fibers, both plants and minerals (basalt) as green constituents of friction materials. In order to promote their wide diffusion, some issues still need to be faced. For example, the bonding strength between the fibers and the matrix in absence of treatments using chemicals with high environmental impact should be improved.

\subsection{Friction Modifier}

In the automotive industry, replacement of friction modifiers with environmentally friendly compounds should endow the final material with a stable friction coefficient and a decreased wear rate at diverse operating speeds, pressures, temperatures and climatic conditions. As mentioned in the previous section, the most common materials used as friction modifiers are: quartz, silica, alumina, silicon carbide, mullite, zircon, zirconium silicate, zirconia and chromium oxide as abrasives and tin sulphide, antimony trisulphide and graphite in different forms, such as natural, flake, synthetic and polarized, as solid lubricants [88]. Although some concerns about potential risks of copper and antimony lead to environmental regulations for limiting their use, most of the friction modifiers are considered safe. This is probably the reason why few works about ecofriendly substitutes can be found in literature. Some researchers studied colemanite and ulexite, two boron minerals, as friction composites. Boron is a fundamental element widely used in different sectors such as production of fiberglass and detergents. Boron minerals are not considered green substances like natural fibers, but they are utilized as sources for crop fertilization, and the WHO organization assumed boron safe for human health [180]. Indeed, a positive effect of borax, colemanite and ulexite was observed on human health through an oxidant effect and reducing the genotoxic effects induced by low quantity of heavy metals [181].

Physical and frictional characteristics of composites containing Pinus brutia cone dust and colemanite indicated they can be promising green constituents [182].

Adding ulexite to a composite improved tribological properties and braking performance: in particular, when ulexite amount increased, an increase in the friction coefficient was noticed, although wear enhancement was observed where ulexite was in the form of dust [183].

Ahlawat et al. utilized white ark shell powder, a natural sea waste, as an abrasive component and compared its performance with that of two commercial abrasives: quartz sand and CNSL powder. Grey cast iron volume loss was ranked as follows: quartz sand $>$ CNSL powder $>$ white ark shell powder [184]. Seashell was used also by Bretotean and coworkers, even though they categorized this material as a filler. Different composites 
with embedded shell, metals, silicon carbide, graphite and hexamethylenetetramine in phenolic resin were compared. An increase in seashell quantity led to an increase in density, hardness, compressive strength and Young modulus. Values of friction coefficients were inside the recommended standard for small and medium automotive friction materials [185]. Walnut was used as a friction modifier by Akıncığlu et al. and the performance compared with a commercial Clio brake tip: different contents of walnut ( 3.5 and $7 \%$ ) in the friction materials exhibited performance similar to commercial materials [186].

Periwinkle shell particles as abrasives were tested by Obot et al., showing that increasing concentration from 4 to $12 \mathrm{wt} \%$. provoked a progressive increase in hardness and compressive strength while decreasing wear rate [187].

Periwinkle shell particles were also studied for their physical, mechanical and tribological properties within five sets of friction materials with varying periwinkle shell sieve size $(710-125 \mu \mathrm{m})$. When particle size decreased, good interfacial bonding was observed, while the best overall properties were obtained adding periwinkle shell with particle size of 125 microns [188].

In conclusion, the addition of seashell in phenolic-resin-based composites results in friction materials with proper friction coefficients and enhanced mechanical properties. In addition, walnut appears as a promising green constituent because its addition in friction materials does not reduce overall performance. Periwinkle shell, too, can be considered as valuable additive when proper size is employed.

\subsection{Fillers}

Few works are found in literature in the case of fillers. A filler based on ground nut shells resulted in reducing friction material cost, but high friction coefficients compared with the traditional values were found [189].

The addition of $10 \%(\mathrm{wt})$ zeolite led to a constant and higher frictional coefficient and lower wear rate [190].

Chandradass et al. (2021) fabricated friction materials using agrowaste sugar cane bagasse ash as a filler in different proportions ( $0 \%, 5 \%$ and $10 \%$ weight), utilizing epoxy resin as a binder. Results indicated that the sample with $10 \%$ agro waste had high tensile and flexural strength. From a tribological standpoint, a higher friction coefficient was obtained adding 5\% agro waste, while the sample containing $10 \%$ sugar cane bagasse ash showed the highest wear rate [191].

Rice husk, an agroindustrial waste product obtained from the outer shell of rice grains, induced better wear resistance than asbestos friction materials when a $20 \%$ filler carbonized in 100 mesh size particles was utilized [192]. Embedding 80 and 100 rice husk dust mesh in a friction material and evaluating hardness and impact resistance properties indicated that composites with smaller particle size and higher filler percentages resulted in better properties [193]. Multiwall carbon nanotube (MWCNT) increased friction and fade performance while decreasing wear performance. As far as nanoclay, an improvement of wear properties and a drop in friction performance was observed [194].

As concluding remarks, zeolite and rice husk seem the most promising green fillers, since they induce higher wear resistance in friction materials.

\section{Friction Materials from Industrial Waste}

Researchers have been prompted to produce new solutions utilizing waste resources as a result of increasing environmental concern and circular economy. Slags, fly ashes, dusts and sludge are only some of the by-products and wastes created by the metallurgical industry. In the automotive sector, one of the main waste materials is tire. Tire rubber waste particles have been explored as useful additives to nonasbestos organic friction material compounds. Limited tire waste rubber led to a high and constant coefficient of friction, low fade, low frictional variability and the minimum variations during sliding, while, when employing a high content of tire, the most recovery, the least wear and the lowest disc temperature rise were found [195]. 
Basalt and aramid recycled fibers, used as reinforcements, enhanced mechanical and thermal properties when increasing content from 5 to $25 \mathrm{wt} \%$ [196].

Singh et al. investigated the physical, mechanical and tribological characteristics of cement kiln dust, a significant waste product in the cement industry, when it was filled with various resins (straight phenolic, cashew-nut-shell-liquid-modified, linseed-oil-modified and alkyl-benzene-modified). Results showed that a combination of cement kiln dust and cashew-nut-shell-liquid/linseed-oil-modified resin enhanced both recovery and wear performance and reduced variability in friction [197].

Fly ash, produced during the combustion of coal for energy production, is an industrial by-product considered an environmental pollutant. Most fly ashes are made of silica, alumina, calcium sulphate and unburnt carbon [198]. Friction material composites containing various mixtures of zinc borate and fly ash (i.e., $0-5 \mathrm{wt} \%$ zinc borate and $65-60 \mathrm{wt} \%$ fly ash) had superior friction stability. Decreased wear rate was obtained by increasing zinc borate and decreasing fly ash contents [199]. Satapathy et al. studied mechanical and tribological behavior of composites made by different combinations of flay ash and mineral rock fiber. Better mechanical properties were obtained for composites with low fly ash and high lapinus fiber, while higher wear resistance was obtained with high fly ash and low lapinus fiber [200].

Slag fibers of 0.5-5.5 microns in diameter were produced by fiber blowing equipment from water-quenched slags. Slag fiber, embedded in phenol-formaldehyde resin, led to an increase in friction coefficients and reduction in wear [201].

Slate, a metamorphic rock mineral, was used as a friction material component with the aim to reduce the environmental impact caused by its inadequate disposal. Varying slate percentage, the authors found that friction materials with $40 \%$ of slate and $35 \%$ of phenolic resin offered better performance compared to commercial friction materials [57].

Cenosphere, a fraction of coal fly ash, and barium sulphate as fillers were compared. Figure 11 shows the spherical morphology of cenosphere, which presented a hollow nature. Lower densities, higher wear resistance, enhanced recovery, lower disc temperature increase and fluctuation in the friction coefficient were observed with respect to the friction material composite with barium sulphate [202].

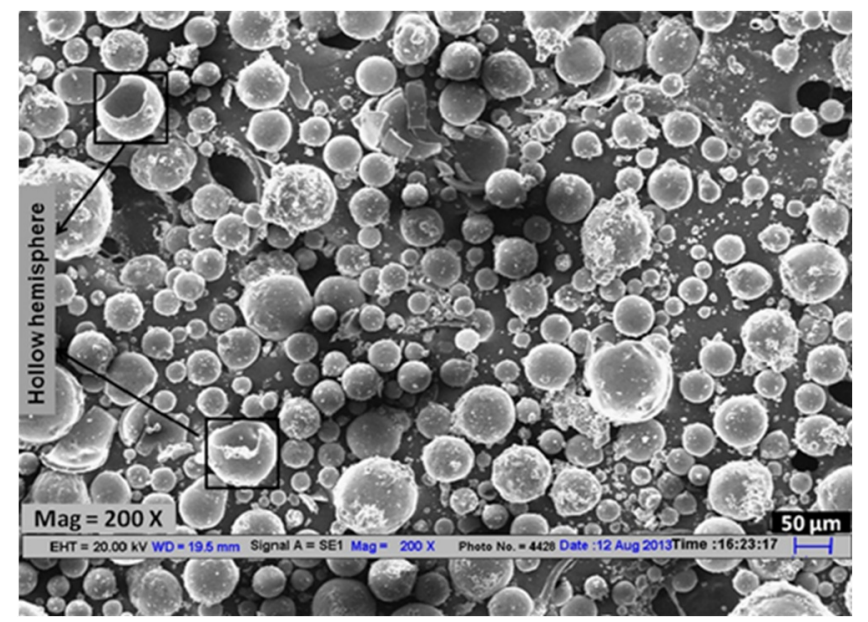

Figure 11. Cenosphere particles (courtesy of Tiwari et al. [202]).

In summary, some promising examples of waste from industry as constituents of brake pads have been individuated. Indeed, tire rubber, kiln dust, fly ash, slag fibers, slate and cenosphere were found suitable additives for friction materials, allowing for the preparation of composites fulfilling the proper requirements.

Finally, friction material waste could be also taken into consideration in view of a circular economy, as they cannot be degraded naturally, causing environmental pollution. It should be underlined that before they become completely worn out, rotor and friction 
materials are usually exchanged with new ones: an automobile requires 16 spare sets of brake pads and four rotors throughout the course of its lifetime [203].

To address this issue, in recent years, many researchers have attempted to use friction material waste as mineral fillers in asphalt [204] or to add them to geopolymers [205].

\section{Conclusions}

The new environmental regulations have increased the demand for brake systems producing low-polluting compounds. Indeed, particulate matter in the nonexhaust category is mainly emitted by friction materials. With the aim to reduce toxic substances enclosed in brake pads, several attempts to replace them with natural fibers have been made in the last ten years. The main outcomes for each category of friction material constituents can be summarized as follows.

\subsection{A: Binder}

Phenolic resin is the most widely utilized form of the friction material matrix, owing to its inexpensive cost. Volatile organic compounds, such as formaldehyde, may be released during the manufacture of friction materials. Furthermore, high-temperature organic-based hazardous compounds can be produced during braking events.

Little research concerning the elimination of phenolic resin is present in literature. Most of the works are related to the improvement of phenolic resin mechanical properties and friction performance in fade and recovery conditions. As a possible substitute to phenolic resin, researchers try to use lignin, a phenolic polymer forming the plant cell wall. The advantages of using lignin as a binder are related to a more stable friction coefficient.

Geopolymers and bioresins are also considered. A comparable mechanical strength with traditional friction materials has been achieved using bioresin, while promising results in terms of general performance were obtained with geopolymers.

\subsection{B: Fibers}

Various natural fibers were evaluated and the majority of the studies demonstrated that environmentally benign materials had the potential to replace asbestos in friction material manufacturing. However, the intrinsic properties of natural fibers limit their use to certain applications. Indeed, they are less regular and uniform than the man-made fibers and present poor wettability and incompatibility with some polymeric matrices. Chemical treatments are necessary to improve mechanical properties, providing promising opportunities in the friction material market. Moreover, many studies have found a strong dependence of mechanical properties on both fiber orientation and fiber length.

It is difficult to establish which fibers could be the best candidates to be used for friction materials, as it is often difficult to compare properties among different published works. It could be inferred from the present literature study that the most promising natural fibers have been patented. From research on the EU Patent Office site, fibers of palm kernel, flax, agave and aloe can be identified as the most promising.

\subsection{C: Friction Modifier}

As for the binder, few papers on friction modifiers can be found in literature. Although some of the main friction modifiers used in friction material formulation cannot be considered completely green materials, they are nontoxic for humans and the environment. Some interesting papers dealing with two boron compounds, such as ulexite and colemanite, report promising results.

\subsection{D: Filler}

Rice husk, ground nut shell, periwinkle shell along with maize husk can be valid alternatives to conventional fillers. Moreover, it also emerged that unlike fibers, a chemical treatment is not necessary. Along with the use of natural products to replace synthetic products, there has been also an increase in the use of waste as a substitute. Indeed, tire 
rubber, aramid recycled fibers and cement from the cement industry have been the subject of some research papers.

Author Contributions: Conceptualization, G.G.d.C.; writing—review and editing, G.G.d.C. and M.G.F. All authors have read and agreed to the published version of the manuscript.

Funding: This research received no external funding.

Institutional Review Board Statement: Not applicable.

Informed Consent Statement: Not applicable.

Data Availability Statement: Not applicable.

Conflicts of Interest: The authors declare no conflict of interest.

\begin{tabular}{ll}
\multicolumn{2}{l}{ Abbreviation } \\
PM & Particulate matter \\
WHO & World Health Organization \\
IT & Interim targets \\
EPA & Environmental Protection Agency \\
USAEPA & National Ambient Air Quality Standards (NAAQS) \\
BPWD & Brake pad wear debris \\
US EPA & United States Environmental Protection Agency \\
IARC & International Agency for Research on Cancer \\
LM & Low Metallic \\
SM & Semimetallic \\
NAO & Nonasbestos organic \\
PF & Phenolic resin \\
CVD & Cardiovascular diseases \\
BFM & Brake friction materials \\
BPW & Brake pads waste \\
CNSL & Cashew nut shell liquid \\
NBR & Nitrile butadiene \\
EPO & European Patent Office
\end{tabular}

\section{References}

1. El-Fadel, M.; Massoud, M. Particulate matter in urban areas: Health-based economic assessment. Sci. Total Environ. 2000, 257, 133-146. [CrossRef]

2. Cambra-López, M.; Aarnink, A.J.A.; Zhao, Y.; Calvet, S.; Torres, A.G. Airborne particulate matter from livestock production systems: A review of an air pollution problem. Environ. Pollut. 2010, 158, 1-17. [CrossRef]

3. Kastury, F.; Smith, E.; Juhasz, A.L. A critical review of approaches and limitations of inhalation bioavailability and bioaccessibility of metal(loid)s from ambient particulate matter or dust. Sci. Total Environ. 2017, 574, 1054-1074. [CrossRef] [PubMed]

4. Martinelli, N.; Olivieri, O.; Girelli, D. Air particulate matter and cardiovascular disease: A narrative review. Eur. J. Intern. Med. 2013, 24, 295-302. [CrossRef]

5. Kelly, F.J.; Fussell, J.C. Size, source and chemical composition as determinants of toxicity attributable to ambient particulate matter. Atmos. Environ. 2012, 60, 504-526. [CrossRef]

6. Perrone, M.G.; Gualtieri, M.; Consonni, V.; Ferrero, L.; Sangiorgi, G.; Longhin, E.; Ballabio, D.; Bolzacchini, E.; Camatini, M. Particle size, chemical composition, seasons of the year and urban, rural or remote site origins as determinants of biological effects of particulate matter on pulmonary cells. Environ. Pollut. 2013, 176, 215-227. [CrossRef] [PubMed]

7. Maté, T.; Guaita, R.; Pichiule, M.; Linares, C.; Díaz, J. Short-term effect of fine particulate matter (PM2.5) on daily mortality due to diseases of the circulatory system in Madrid (Spain). Sci. Total Environ. 2010, 408, 5750-5757. [CrossRef]

8. Atkinson, R.W.; Kang, S.; Anderson, H.R.; Mills, I.C.; Walton, H.A. Epidemiological time series studies of PM2.5 and daily mortality and hospital admissions: A systematic review and meta-analysis. Thorax 2014, 69, 660-665. [CrossRef]

9. Wu, C.F.; Woodward, A.; Li, Y.R.; Kan, H.; Balasubramanian, R.; Latif, M.T.; Sahani, M.; Cheng, T.J.; Chio, C.P.; Taneepanichskul, N.; et al. Regulation of fine particulate matter (PM2.5) in the Pacific Rim: Perspectives from the APRU Global Health Program. Air Qual. Atmos. Health 2017, 10, 1039-1049. [CrossRef]

10. Liu, Z.; Wang, F.; Li, W.; Yin, L.; Wang, Y.; Yan, R.; Lao, X.Q.; Kan, H.; Tse, L.A. Does utilizing WHO's interim targets further reduce the risk-Meta-analysis on ambient particulate matter pollution and mortality of cardiovascular diseases? Environ. Pollut. 2018, 242, 1299-1307. [CrossRef] 
11. Implications of Changing PM10 Air Quality Standards on Pacific Northwest Communities Affected by Windblown dust I Elsevier Enhanced Reader. Available online: https:/ / reader.elsevier.com/reader/sd/pii/S1352231011005760?token=E4D49EC40B2020781 58567371242358AD1F2C26F483B91FFD3740BBB3FC3123DBEFC7DC417A8170BC7FEBB8232640699\&originRegion=eu-west-1\& originCreation $=20210511124012$ (accessed on 11 May 2021).

12. Patel, P.; Aggarwal, S.G.; Tsai, C.J.; Okuda, T. Theoretical and field evaluation of a PM2.5 high-volume impactor inlet design. Atmos. Environ. 2021, 244, 17811. [CrossRef]

13. Naing, N.N.; Lee, H.K. Microextraction and analysis of contaminants adsorbed on atmospheric fine particulate matter: A review. J. Chromatogr. A 2020, 1627, 461433. [CrossRef] [PubMed]

14. Kim, K.H.; Kabir, E.; Kabir, S. A review on the human health impact of airborne particulate matter. Environ. Int. 2015, 74, 136-143. [CrossRef] [PubMed]

15. Harrison, R.M.; Yin, J. Particulate matter in the atmosphere: Which particle properties are important for its effects on health? Sci. Total Environ. 2000, 249, 85-101. [CrossRef]

16. Klimenko, A. Aggregated toxicity of road vehicles as basis for future regulation in the field of atmospheric air protection. $S N$ Appl. Sci. 2020, 2, 2050. [CrossRef]

17. Han, X.; Naeher, L.P. A review of traffic-related air pollution exposure assessment studies in the developing world. Environ. Int. 2006, 32, 106-120. [CrossRef]

18. Beji, A.; Deboudt, K.; Khardi, S.; Muresan, B.; Flament, P.; Fourmentin, M.; Lumière, L. Non-exhaust particle emissions under various driving conditions: Implications for sustainable mobility. Transp. Res. Part D Transp. Environ. 2020, 81, 102290. [CrossRef]

19. Grigoratos, T.; Martini, G. Brake wear particle emissions: A review. Environ. Sci. Pollut. Res. 2015, 22, 2491-2504. [CrossRef]

20. Karagulian, F.; Belis, C.A.; Dora, C.F.C.; Prüss-Ustün, A.M.; Bonjour, S.; Adair-Rohani, H.; Amann, M. Contributions to cities' ambient particulate matter (PM): A systematic review of local source contributions at global level. Atmos. Environ. 2015, 120, 475-483. [CrossRef]

21. Maiorana, S.; Teoldi, F.; Silvani, S.; Mancini, A.; Sanguineti, A.; Mariani, F.; Cella, C.; Lopez, A.; Potenza, M.A.C.; Lodi, M.; et al. Phytotoxicity of wear debris from traditional and innovative brake pads. Environ. Int. 2019, 123, 156-163. [CrossRef]

22. Dodd, M.D.; Ebbs, S.D.; Gibson, D.J.; Filip, P. Alteration of root growth by lettuce, wheat, and soybean in response to wear debris from automotive brake pads. Arch. Environ. Contam. Toxicol. 2014, 67, 557-564. [CrossRef] [PubMed]

23. Volta, A.; Sforzini, S.; Camurati, C.; Teoldi, F.; Maiorana, S.; Croce, A.; Benfenati, E.; Perricone, G.; Lodi, M.; Viarengo, A. Ecotoxicological effects of atmospheric particulate produced by braking systems on aquatic and edaphic organisms. Environ. Int. 2020, 137, 105564. [CrossRef] [PubMed]

24. Gasser, M.; Riediker, M.; Mueller, L.; Perrenoud, A.; Blank, F.; Gehr, P.; Rothen-Rutishauser, B. Toxic effects of brake wear particles on epithelial lung cells in vitro. Part. Fibre Toxicol. 2009, 6, 30. [CrossRef] [PubMed]

25. Kakooei, H.; Marioryad, H. Evaluation of exposure to the airborne asbestos in an automobile brake and clutch manufacturing industry in Iran. Regul. Toxicol. Pharmacol. 2010, 56, 143-147. [CrossRef]

26. Paustenbach, D.J.; Finley, B.L.; Lu, E.T.; Brorby, G.P.; Sheehan, P.J. Environmental and occupational health hazards associated with the presence of asbestos in brake linings and pads (1900 to present): A "state-of-the-art" review. J. Toxicol. Environ. Health Part B Crit. Rev. 2004, 7, 25-80. [CrossRef]

27. Takahashi, K.; Landrigan, P.J. The Global Health Dimensions of Asbestos and Asbestos-Related Diseases. Ann. Glob. Health 2016, 82, 209-213. [CrossRef]

28. Poland, C.A.; Duffin, R. Critical Reviews in Toxicology The toxicology of chrysotile-containing brake debris: Implications for mesothelioma. Crit. Rev. Toxicol. 2019, 49, 11-35. [CrossRef]

29. Mahale, V.; Bijwe, J.; Sinha, S. Influence of nano-potassium titanate particles on the performance of NAO brake-pads. Wear 2017, 376-377, 727-737. [CrossRef]

30. Cho, K.H.; Cho, M.H.; Kim, S.J.; Jang, H. Tribological properties of potassium titanate in the brake friction material; morphological effects. Tribol. Lett. 2008, 32, 59-66. [CrossRef]

31. Jadhav, S.P.; Sawant, S.H. A review paper: Development of novel friction material for vehicle brake pad application to minimize environmental and health issues. Mater. Today Proc. 2019, 19, 209-212. [CrossRef]

32. Straffelini, G.; Ciudin, R.; Ciotti, A.; Gialanella, S. Present knowledge and perspectives on the role of copper in brake materials and related environmental issues: A critical assessment. Environ. Pollut. 2015, 207, 211-219. [CrossRef] [PubMed]

33. Figliuzzi, M.; Tironi, M.; Longaretti, L.; Mancini, A.; Teoldi, F.; Sangalli, F.; Remuzzi, A. Copper-dependent biological effects of particulate matter produced by brake systems on lung alveolar cells. Arch. Toxicol. 2020, 94, 2965-2979. [CrossRef] [PubMed]

34. Zhang, M.; Guo, X.; Tian, B.; Wang, J.; Qi, S.; Yang, Y.; Xin, B. Improved bioleaching of copper and zinc from brake pad waste by low-temperature thermal pretreatment and its mechanisms. Waste Manag. 2019, 87, 629-635. [CrossRef] [PubMed]

35. Grigoratos, T. Regulation on Brake/Tire Composition; Elsevier: Amsterdam, The Netherlands, 2018; ISBN 9780128117705.

36. Fujiwara, F.; Rebagliati, R.J.; Marrero, J.; Gómez, D.; Smichowski, P. Antimony as a traffic-related element in size-fractionated road dust samples collected in Buenos Aires. Microchem. J. 2011, 97, 62-67. [CrossRef]

37. Li, J.; Zheng, B.H.; He, Y.; Zhou, Y.; Chen, X.; Ruan, S.; Yang, Y.; Dai, C.; Tang, L. Antimony contamination, consequences and removal techniques: A review. Ecotoxicol. Environ. Saf. 2018, 156, 125-134. [CrossRef] 
38. Iijima, A.; Sato, K.; Yano, K.; Tago, H.; Kato, M.; Kimura, H.; Furuta, N. Particle size and composition distribution analysis of automotive brake abrasion dusts for the evaluation of antimony sources of airborne particulate matter. Atmos. Environ. 2007, 41, 4908-4919. [CrossRef]

39. Halada, K. Progress of ecomaterials toward a sustainable society. Curr. Opin. Solid State Mater. Sci. 2003, 7, 209-216. [CrossRef]

40. Papinniemi, A.; Lai, J.C.S.; Zhao, J.; Loader, L. Brake squeal: A literature review. Appl. Acoust. 2002, 63, 391-400. [CrossRef]

41. Kchaou, M.; Sellami, A.; Elleuch, R.; Singh, H. Friction characteristics of a brake friction material under different braking conditions. Mater. Des. 2013, 52, 533-540. [CrossRef]

42. Aranke, O.; Algenaid, W.; Awe, S.; Joshi, S. Coatings for automotive gray cast iron brake discs: A review. Coatings 2019, 9, 552. [CrossRef]

43. Blau, P.J.; Jolly, B.C.; Qu, J.; Peter, W.H.; Blue, C.A. Tribological investigation of titanium-based materials for brakes. Wear 2007, 263, 1202-1211. [CrossRef]

44. Chan, D.; Stachowiak, G.W. Review of automotive brake friction materials. Proc. Inst. Mech. Eng. Part D J. Automob. Eng. 2004, 218, 953-966. [CrossRef]

45. EL-Tayeb, N.S.M.; Liew, K.W. On the dry and wet sliding performance of potentially new frictional brake pad materials for automotive industry. Wear 2009, 266, 275-287. [CrossRef]

46. Saindane, U.V.; Soni, S.; Menghani, J.V. Recent research status on synthesis and characterization of natural fibers reinforced polymer composites and modern friction materials-An overview. Mater. Today Proc. 2020, 26, 1616-1620. [CrossRef]

47. Nosko, O.; Olofsson, U. Effective density of airborne wear particles from car brake materials. J. Aerosol Sci. 2017, 107, 94-106. [CrossRef]

48. Faga, M.G.; Casamassa, E.; Iodice, V.; Sin, A.; Gautier, G. Morphological and structural features affecting the friction properties of carbon materials for brake pads. Tribol. Int. 2019, 140, 105889. [CrossRef]

49. Baklouti, M.; Cristol, A.L.; Desplanques, Y.; Elleuch, R. Impact of the glass fibers addition on tribological behavior and braking performances of organic matrix composites for brake lining. Wear 2015, 330, 507-514. [CrossRef]

50. Kumar, V.V.; Kumaran, S.S. Friction material composite: Types of brake friction material formulations and effects of various ingredients on brake performance-a review. Mater. Res. Express 2019, 6, 082005. [CrossRef]

51. Wei, L.; Choy, Y.S.; Cheung, C.S. A study of brake contact pairs under different friction conditions with respect to characteristics of brake pad surfaces. Tribol. Int. 2019, 138, 99-110. [CrossRef]

52. Sinha, A.; Ischia, G.; Menapace, C.; Gialanella, S. Experimental characterization protocols for wear products from disc brake materials. Atmosphere 2020, 11, 1102. [CrossRef]

53. Aleksendrić, D.; Carlone, P. Soft Computing in the Design and Manufacturing of Composite Materials; Elesevier: Amsterdam, The Netherlands, 2015; ISBN 9781782421801.

54. Venkatesh, S.; Murugapoopathiraja, K. Scoping review of brake friction material for automotive. Mater. Today Proc. 2019, 16, 927-933. [CrossRef]

55. Kukutschová, J.; Filip, P. Review of Brake Wear Emissions: A Review of Brake Emission Measurement Studies: Identification of Gaps and Future Needs; Elesevier: Amsterdam, The Netherlands, 2018; ISBN 9780128117705.

56. Cai, P.; Wang, Y.; Wang, T.; Wang, Q. Effect of resins on thermal, mechanical and tribological properties of friction materials. Tribol. Int. 2015, 87, 1-10. [CrossRef]

57. Binda, F.F.; De Alvarenga Oliveira, V.; Fortulan, C.A.; Palhares, L.B.; Dos Santos, C.G. Friction elements based on phenolic resin and slate powder. J. Mater. Res. Technol. 2020, 9, 3378-3383. [CrossRef]

58. Gurunath, P.V.; Bijwe, J. Friction and wear studies on brake-pad materials based on newly developed resin. Wear 2007, 263, 1212-1219. [CrossRef]

59. Bijwe, J.; Nidhi; Majumdar, N.; Satapathy, B.K. Influence of modified phenolic resins on the fade and recovery behavior of friction materials. Wear 2005, 259, 1068-1078. [CrossRef]

60. Kim, S.J.; Jang, H. Friction and wear of friction materials containing two different phenolic resins reinforced with aramid pulp. Tribol. Int. 2000, 33, 477-484. [CrossRef]

61. Wu, Y.; Zeng, M.; Xu, Q.; Hou, S.; Jin, H.; Fan, L. Effects of glass-to-rubber transition of thermosetting resin matrix on the friction and wear properties of friction materials. Tribol. Int. 2012, 54, 51-57. [CrossRef]

62. Ghosh, P.; Banerjee, S.S.; Khastgir, D. Performance assessment of hybrid fibrous fillers on the tribological and thermo-mechanical behaviors of elastomer modified phenolic resin friction composite. SN Appl. Sci. 2020, 2, 788. [CrossRef]

63. Kim, S.J.; Cho, M.H.; Lim, D.S.; Jang, H. Synergistic effects of aramid pulp and potassium titanate whiskers in the automotive friction material. Wear 2001, 251, 1484-1491. [CrossRef]

64. ÖZtüRk, B.; Arslan, F.; Öztürk, S. Effects of different kinds of fibers on mechanical and tribological properties of brake friction materials. Tribol. Trans. 2013, 56, 536-545. [CrossRef]

65. Singh, T.; Patnaik, A.; Chauhan, R.; Chauhan, P. Selection of brake friction materials using hybrid analytical hierarchy process and vise Kriterijumska Optimizacija Kompromisno Resenje approach. Polym. Compos. 2018, 39, 1655-1662. [CrossRef]

66. Qu, X.; Zhang, L.; Ding, H.; Liu, G. The Effect of Steel Fiber Orientation on Frictional Properties of Asbestos-Free Friction Materials. Polym. Compos. 2004, 25, 94-101. [CrossRef]

67. Öztürk, B.; Öztürk, S. Effects of resin type and fiber length on the mechanical and tribological properties of brake friction materials. Tribol. Lett. 2011, 42, 339-350. [CrossRef] 
68. Öztürk, B.; Arslan, F.; Öztürk, S. Hot wear properties of ceramic and basalt fiber reinforced hybrid friction materials. Tribol. Int. 2007, 40, 37-48. [CrossRef]

69. Casamassa, E.; Gautier, G.; Sin, A.; Kukutschova, J.; Faga, M.G. Granular and platelet titanate as promising brake pads ingredients. Open Ceram. 2021, 6, 100128. [CrossRef]

70. Kumar, M.; Satapathy, B.K.; Patnaik, A.; Kolluri, D.K.; Tomar, B.S. Evaluation of fade-recovery performance of hybrid friction composites based on ternary combination of ceramic-fibers, ceramic-whiskers, and aramid-fibers. J. Appl. Polym. Sci. 2012, 124, 3650-3661. [CrossRef]

71. Singh, T.; Tiwari, A.; Patnaik, A.; Chauhan, R.; Ali, S. Influence of wollastonite shape and amount on tribo-performance of non-asbestos organic brake friction composites. Wear 2017, 386, 157-164. [CrossRef]

72. Aranganathan, N.; Bijwe, J. Special grade of graphite in NAO friction materials for possible replacement of copper. Wear 2015, 330, 515-523. [CrossRef]

73. Jang, H.; Ko, K.; Kim, S.J.; Basch, R.H.; Fash, J.W. The effect of metal fibers on the friction performance of automotive brake friction materials. Wear 2004, 256, 406-414. [CrossRef]

74. Sterle, W.; Prietzel, C.; Kloß, H.; Dmitriev, A.I. On the role of copper in brake friction materials. Tribol. Int. 2010, 43, 2317-2326. [CrossRef]

75. Sundarkrishnaa, K.L. Friction Material Composites; Springer International Publishing: Berlin/Heidelberg, Germany, 2015.

76. Singh, T.; Patnaik, A.; Chauhan, R.; Rishiraj, A. Assessment of braking performance of lapinus-wollastonite fibre reinforced friction composite materials. J. King Saud Univ.-Eng. Sci. 2017, 29, 183-190. [CrossRef]

77. Tátrai, E.; Kováčiková, Z.; Broózik, M.; Six, É. Pulmonary toxicity of wollastonite in vivo and in vitro. J. Appl. Toxicol. 2004, 24, 147-154. [CrossRef] [PubMed]

78. Xin, X.; Xu, C.G.; Qing, L.F. Friction properties of sisal fibre reinforced resin brake composites. Wear 2007, 262, 736-741. [CrossRef]

79. Fei, J.; Wang, H.K.; Huang, J.F.; Zeng, X.R.; Luo, W. Effects of carbon fiber length on the tribological properties of paper-based friction materials. Tribol. Int. 2014, 72, 179-186. [CrossRef]

80. Bagheri Kazem Abadi, S.; Khavandi, A.; Kharazi, Y. Effects of mixing the steel and carbon fibers on the friction and wear properties of a PMC friction material. Appl. Compos. Mater. 2010, 17, 151-158. [CrossRef]

81. Manoharan, S.; Sai Krishnan, G.; Ganesh Babu, L.; Vijay, R.; Lenin Singaravelu, D. Synergistic effect of red mud-iron sulfide particles on fade-recovery characteristics of non-asbestos organic brake friction composites. Mater. Res. Express 2019, 6, 105311. [CrossRef]

82. Shin, M.W.; Kim, Y.H.; Jang, H. Effect of the Abrasive Size on the Friction Effectiveness and Instability of Brake Friction Materials: A Case Study with Zircon. Tribol. Lett. 2014, 55, 371-379. [CrossRef]

83. Jang, H.; Kim, S.J. The effects of antimony trisulfide (Sb2S3) and zirconium silicate ( $\mathrm{ZrSiO} 4)$ in the automotive brake friction material on friction characteristics. Wear 2000, 239, 229-236. [CrossRef]

84. Jeganmohan, S.; Sugozu, B.; Kumar, M.; Selvam, D.R. Experimental Investigation on the Friction and Wear Characteristics of Palm Seed Powder Reinforced Brake Pad Friction Composites. J. Inst. Eng. Ser. D 2020, 101, 61-69. [CrossRef]

85. Matějka, V.; Lu, Y.; Fan, Y.; Kratošová, G.; Lešková, J. Effects of silicon carbide in semi-metallic brake materials on friction performance and friction layer formation. Wear 2008, 265, 1121-1128. [CrossRef]

86. Cho, M.H.; Ju, J.; Kim, S.J.; Jang, H. Tribological properties of solid lubricants (graphite, Sb2S3, MoS2) for automotive brake friction materials. Wear 2006, 260, 855-860. [CrossRef]

87. Kim, S.J.; Hyung Cho, M.; Hyung Cho, K.; Jang, H. Complementary effects of solid lubricants in the automotive brake lining Tribol. Int. 2007, 40, 15-20. [CrossRef]

88. Kim, S.S.; Hwang, H.J.; Shin, M.W.; Jang, H. Friction and vibration of automotive brake pads containing different abrasive particles. Wear 2011, 271, 1194-1202. [CrossRef]

89. Dufresne, A.; Bégin, R.; Dion, C.; Jagirdar, J.; Rom, W.N.; Loosereewanich, P.; Muir, D.C.F.; Ritchie, A.C.; Perrault, G. Angular and fibrous particles in lung in relation to silica-induced diseases. Int. Arch. Occup. Environ. Health 1998, 71, 263-269. [CrossRef] [PubMed]

90. Rödelsperger, K.; Brückel, B. The carcinogenicity of WHO fibers of silicon carbide: SiC whiskers compared to cleavage fragments of granular SiC. Inhal. Toxicol. 2006, 18, 623-631. [CrossRef] [PubMed]

91. Manoharan, S.; Vijay, R.; Lenin Singaravelu, D.; Kchaou, M. Experimental Investigation on the Tribo-Thermal Properties of Brake Friction Materials Containing Various Forms of Graphite: A Comparative Study. Arab. J. Sci. Eng. 2019, 44, 1459-1473. [CrossRef]

92. Balaji, S.; Mohamed Aslam Noorani, A.B. Tribological performance of graphene/graphite filled phenolic composites-A comparative study. Compos. Commun. 2019, 15, 34-39. [CrossRef]

93. Österle, W.; Dmitriev, A.I. The role of solid lubricants for brake friction materials. Lubricants 2016, 4, 5. [CrossRef]

94. Suvorov, S.A.; Skurikhin, V.V. Vermiculite-a promising material for high-temperature heat insulators. Refract. Ind. Ceram. 2003, 44, 186-193. [CrossRef]

95. Xu, X.L.; Lu, X.; Yang, D.L.; Zhang, E. Effects of vermiculite on the tribological behavior of PI-matrix friction materials. IOP Conf. Ser. Mater. Sci. Eng. 2015, 87, 012024. [CrossRef]

96. Chamnipan, R.; Chutima, S.; Uthaisangsuk, V. Processing and characterization of nano filler containing friction material. Mater. Today Proc. 2018, 5, 9467-9475. [CrossRef]

97. Dante, R.C. Abrasives, Ceramic, and Inorganic Materials; Elsevier: Amsterdam, The Netherlands, 2016. 
98. Egeonu, D.; Oluah, C.; Okolo, P.N. Production of Eco-Friendly Brake Pad Using Raw Materials Sourced Locally In Nsukka. Int. J. Energy Technol. Policy 2015, 5, 47-54.

99. Kosbe, P.; Patil, P.; Manickam, M.; Ramamurthy, G. Effect of hexagonal boron nitride (h-BN) inclusion on thermal characteristics of disc brake friction composites. Diam. Relat. Mater. 2020, 107, 107895. [CrossRef]

100. Jang, H.; Lee, J.S.; Fash, J.W. Compositional effects of the brake friction material on creep groan phenomena. Wear 2001, 250, 1477-1483. [CrossRef]

101. Almaslow, A.; Ghazali, M.J.; Talib, R.J.; Ratnam, C.T.; Azhari, C.H. Effects of epoxidized natural rubber-alumina nanoparticles (ENRAN) composites in semi-metallic brake friction materials. Wear 2013, 302, 1392-1396. [CrossRef]

102. Nakason, C.; Wannavilai, P.; Kaesaman, A. Effect of vulcanization system on properties of thermoplastic vulcanizates based on epoxidized natural rubber/polypropylene blends. Polym. Test. 2006, 25, 34-41. [CrossRef]

103. Thiyagarajan, V.; Kalaichelvan, K.; Vijay, R.; Lenin Singaravelu, D. Influence of thermal conductivity and thermal stability on the fade and recovery characteristics of non-asbestos semi-metallic disc brake pad. J. Braz. Soc. Mech. Sci. Eng. 2016, 38, 1207-1219. [CrossRef]

104. Satapathy, B.K.; Patnaik, A.; Dadkar, N.; Kolluri, D.K.; Tomar, B.S. Influence of vermiculite on performance of flyash-based fibre-reinforced hybrid composites as friction materials. Mater. Des. 2011, 32, 4354-4361. [CrossRef]

105. Sudhan Raj, J.; Christy, T.V.; Darius Gnanaraj, S.; Sugozu, B. Influence of calcium sulfate whiskers on the tribological characteristics of automotive brake friction materials. Eng. Sci. Technol. Int. J. 2020, 23, 445-451. [CrossRef]

106. Arsada, R.; Surojo, E.; Ariawan, D.; Muhayat, N.; Raharjo, W.W. Effect of NBR (Nitrile Butadiene Rubber) on flexural strength of composite friction brake. IOP Conf. Ser. Mater. Sci. Eng. 2018, 420, 012057. [CrossRef]

107. Basfar, A.A.; Abdel-Aziz, M.M.; Mofti, S. Influence of different curing systems on the physico-mechanical properties and stability of SBR and NR rubbers. Radiat. Phys. Chem. 2002, 63, 81-87. [CrossRef]

108. Singaravelu, D.L.; Vijay, R.; Filip, P. Influence of various cashew friction dusts on the fade and recovery characteristics of non-asbestos copper free brake friction composites. Wear 2019, 426-427, 1129-1141. [CrossRef]

109. Lagel, M.C.; Hai, L.; Pizzi, A.; Basso, M.C.; Delmotte, L.; Abdalla, S.; Zahed, A.; Al-Marzouki, F.M. Automotive brake pads made with a bioresin matrix. Ind. Crops Prod. 2016, 85, 372-381. [CrossRef]

110. Agrawal, A.; Kaushik, N.; Biswas, S. Derivatives and Applications of Lignin-An Insight. SciTech J. 2014, 1, 30-36.

111. Nehez, N.J. Lignin-based friction material. Can. Pat. 1997, 2, 242-554.

112. US9534650B2-Friction Material-Google Patents. Available online: https://patents.google.com/patent/US9534650B2/en?q= brake+pad\%2C+lignin\&oq=brake+pad\%2C+lignin (accessed on 18 June 2021).

113. Park, J.; Hwang, H.; Kim, J.Y.; Choi, J.W. Applicability of lignin polymers for automobile brake pads as binder and filler materials and their performance characteristics. Environ. Technol. 2020, 41, 488-497. [CrossRef]

114. Lee, P.W.; Filip, P. Friction and wear of Cu-free and Sb-free environmental friendly automotive brake materials. Wear 2013, 302, 1404-1413. [CrossRef]

115. Xicola, A.S.; Angeleri, A.; Lupone, F.; Caldarola, D.; Conte, A.; Colombo, P. Friction Material, in Particular for the Manufacturing of a Brake Pad, and Associated Preparation Methods. 2015. Available online: https://patents.google.com/patent/US20170016500 (accessed on 20 January 2022).

116. Thyavihalli Girijappa, Y.G.; Mavinkere Rangappa, S.; Parameswaranpillai, J.; Siengchin, S. Natural Fibers as Sustainable and Renewable Resource for Development of Eco-Friendly Composites: A Comprehensive Review. Front. Mater. 2019, 6, 226. [CrossRef]

117. Riccieri, J.E.; De Carvalho, L.H.; Vázquez, A. Interfacial properties and initial step of the water sorption in unidirectional unsaturated polyester/vegetable fiber composites. Polym. Compos. 1999, 20, 29-37. [CrossRef]

118. Srinivasa, C.V.; Bharath, K.N. Impact and hardness properties of areca fiber-epoxy reinforced composites. J. Mater. Environ. Sci. 2011, 2, 351-356.

119. Li, X.; Tabil, L.G.; Panigrahi, S. Chemical treatments of natural fiber for use in natural fiber-reinforced composites: A review. J. Polym. Environ. 2007, 15, 25-33. [CrossRef]

120. Vilay, V.; Mariatti, M.; Mat Taib, R.; Todo, M. Effect of fiber surface treatment and fiber loading on the properties of bagasse fiber-reinforced unsaturated polyester composites. Compos. Sci. Technol. 2008, 68, 631-638. [CrossRef]

121. Methacanon, P.; Weerawatsophon, U.; Sumransin, N.; Prahsarn, C.; Bergado, D.T. Properties and potential application of the selected natural fibers as limited life geotextiles. Carbohydr. Polym. 2010, 82, 1090-1096. [CrossRef]

122. Lee, S.H.; Wang, S. Biodegradable polymers/bamboo fiber biocomposite with bio-based coupling agent. Compos. Part A Appl. Sci. Manuf. 2006, 37, 80-91. [CrossRef]

123. Aziz, S.H.; Ansell, M.P. The effect of alkalization and fibre alignment on the mechanical and thermal properties of kenaf and hemp bast fibre composites: Part 1-Polyester resin matrix. Compos. Sci. Technol. 2004, 64, 1219-1230. [CrossRef]

124. Rashid, B.; Leman, Z.; Jawaid, M.; Ghazali, M.J.; Ishak, M.R.; Abdelgnei, M.A. Dry sliding wear behavior of untreated and treated sugar palm fiber filled phenolic composites using factorial technique. Wear 2017, 380-381, 26-35. [CrossRef]

125. Ikpambese, K.K.; Gundu, D.T.; Tuleun, L.T. Evaluation of palm kernel fibers (PKFs) for production of asbestos-free automotive brake pads. J. King Saud Univ.-Eng. Sci. 2016, 28, 110-118. [CrossRef]

126. Srinivasa, C.V.; Arifulla, A.; Goutham, N.; Santhosh, T.; Jaeethendra, H.J.; Ravikumar, R.B.; Anil, S.G.; Santhosh Kumar, D.G.; Ashish, J. Static bending and impact behaviour of areca fibers composites. Mater. Des. 2011, 32, 2469-2475. [CrossRef] 
127. Dinakaran, K.; Ramesh, H.; Joseph, A.D.; Murugan, R.; Jothi, S. Development and characterization of areca fiber reinforced polymer composite. Mater. Today Proc. 2019, 18, 934-940. [CrossRef]

128. Bashir, M.; Qayoum, A.; Saleem, S.S. Influence of lignocellulosic banana fiber on the thermal stability of brake pad material. Mater. Res. Express 2019, 6, 115551. [CrossRef]

129. Zhen-Yu, W.; Jie, W.; Feng-Hong, C.; Yun-Hai, M.; Singh, T.; Fekete, G. Influence of banana fiber on physicomechanical and tribological properties of phenolic based friction composites. Mater. Res. Express 2019, 6, 075103. [CrossRef]

130. Nabi Saheb, D.; Jog, J.P. Natural fiber polymer composites: A review. Adv. Polym. Technol. 1999, 18, 351-363. [CrossRef]

131. Gurunathan, T.; Mohanty, S.; Nayak, S.K. A review of the recent developments in biocomposites based on natural fibres and their application perspectives. Compos. Part A Appl. Sci. Manuf. 2015, 77, 1-25. [CrossRef]

132. Hemnath, A.; Anbuchezhiyan, G.; NanthaKumar, P.; Senthilkumar, N. Tensile and flexural behaviour of rice husk and sugarcane bagasse reinforced polyester composites. Mater. Today Proc. 2021, 46, 3451-3454. [CrossRef]

133. Binoj, J.S.; Raj, R.E.; Sreenivasan, V.S.; Thusnavis, G.R. Morphological, Physical, Mechanical, Chemical and Thermal Characterization of Sustainable Indian Areca Fruit Husk Fibers (Areca Catechu L.) as Potential Alternate for Hazardous Synthetic Fibers. J. Bionic Eng. 2016, 13, 156-165. [CrossRef]

134. Ma, Y.; Wu, S.; Zhuang, J.; Tong, J.; Xiao, Y.; Qi, H. The evaluation of physio-mechanical and tribological characterization of friction composites reinforced by waste corn stalk. Materials 2018, 11, 901. [CrossRef]

135. Lawal, S.S.; Ademoh, N.A.; Bala, K.C.; Abdulrahman, A.S. Reviews in Automobile Brake Pads Production and Prospects of Agro Base Composites of Cashew Nut Shells and Nigerian Gum Arabic Binder. Covenant J. Eng. Technol. 2019, 3, 2682-5317. Available online: https:/ /journals.covenantuniversity.edu.ng/index.php/cjet/article/view/1797 (accessed on 20 January 2022).

136. Ahmad, F.; Choi, H.S.; Park, M.K. A Review: Natural Fiber Composites Selection in View of Mechanical, Light Weight, and Economic Properties; Wiley-VCH Verlag: Weinheim, Germany, 2015; Volume 300, pp. 10-24.

137. Ma, Y.; Liu, Y.; Ma, S.; Wang, H.; Gao, Z.; Sun, J.; Tong, J.; Guo, L. Friction and wear properties of dumbbell-shaped jute fiber-reinforced friction materials. J. Appl. Polym. Sci. 2014, 131. [CrossRef]

138. Fiore, V.; Di Bella, G.; Valenza, A. The effect of alkaline treatment on mechanical properties of kenaf fibers and their epoxy composites. Compos. Part B Eng. 2015, 68, 14-21. [CrossRef]

139. Dittenber, D.B.; Gangarao, H.V.S. Critical review of recent publications on use of natural composites in infrastructure. Compos. Part A Appl. Sci. Manuf. 2012, 43, 1419-1429. [CrossRef]

140. Liu, Y.; Ma, Y.; Che, J.; Duanmu, L.; Zhuang, J.; Tong, J. Natural fibre reinforced non-asbestos organic non-metallic friction composites: Effect of abaca fibre on mechanical and tribological behaviour. Mater. Res. Express 2018, 5, 055101. [CrossRef]

141. Bongarde, U.S.; Shinde, V. Review on natural fiber reinforcement polymer composites. Int. J. Eng. Sci. Innov. Technol. 2014, 3, 431-436.

142. Fu, Z.; Suo, B.; Yun, R.; Lu, Y.; Wang, H.; Qi, S.; Jiang, S.; Lu, Y.; Matejka, V. Development of eco-friendly brake friction composites containing flax fibers. J. Reinf. Plast. Compos. 2012, 31, 681-689. [CrossRef]

143. Singh, T.; Pruncu, C.I.; Gangil, B.; Singh, V.; Fekete, G. Comparative performance assessment of pineapple and Kevlar fibers based friction composites. J. Mater. Res. Technol. 2020, 9, 1491-1499. [CrossRef]

144. Biocomposites Reinforced with Natural Fibers: 2000-2010 I Elsevier Enhanced Reader. Available online: https: / reader.elsevier com/reader/sd/pii/S0079670012000391?token=E40D95EC33905B639F8E3841ED0467C85229DD51EF890FEE718C193480543 DB0E70530DA42F4C1428D0A91B1DD0478DF (accessed on 29 March 2021).

145. Bernard, S.S.; Jayakumari, L.S. Pressure and temperature sensitivity analysis of palm fiber as a biobased reinforcement material in brake pad. J. Braz. Soc. Mech. Sci. Eng. 2018, 40, 1-12. [CrossRef]

146. Sai Krishnan, G.; Ganesh Babu, L.; Pradhan, R.; Kumar, S. Study on tribological properties of palm kernel fiber for brake pad applications. Mater. Res. Express 2019, 7, 015102. [CrossRef]

147. Ravikumar, K.; Pridhar, T. Evaluation on properties and characterization of asbestos free palm kernel shell fibre (PKSF)/polymer composites for brake pads. Mater. Res. Express 2019, 6, 1165d2. [CrossRef]

148. Sai Krishnan, G.; Jayakumari, L.S.; Ganesh Babu, L.; Suresh, G. Investigation on the physical, mechanical and tribological properties of areca sheath fibers for brake pad applications. Mater. Res. Express 2019, 6, 085109. [CrossRef]

149. Mustafa, A.; Abdollah, M.F.B.; Shuhimi, F.F.; Ismail, N.; Amiruddin, H.; Umehara, N. Selection and verification of kenaf fibres as an alternative friction material using Weighted Decision Matrix method. Mater. Des. 2015, 67, 577-582. [CrossRef]

150. Ramesh, P.; Krishnan, G.S.; Ragu, R.; Suresh, G.; Srinivasan, S. Investigation on the Physical/Mechanical Properties of NAO brake friction Composites by using Kenaf fiber. IOP Conf. Ser. Mater. Sci. Eng. 2020, 961, 012016. [CrossRef]

151. Paramasivam, K.; Jayaraj, J.J.; Ramar, K.; Subramani, Y.; Ajithkumar, K.; Kabilan, N. Evaluation of natural fibers for the production of automotive brake pads replacement for asbestos brake pad. AIP Conf. Proc. 2020, 2311, 040005.

152. Idris, U.D.; Aigbodion, V.S.; Abubakar, I.J.; Nwoye, C.I. Eco-friendly asbestos free brake-pad: Using banana peels. J. King Saud Univ.-Eng. Sci. 2015, 27, 185-192. [CrossRef]

153. Sai Krishnan, G.; Shanmugasundar, G.; Vanitha, M.; Sivashanmugam, N. Mechanical Properties of Chemically Treated Banana and Ramie Fibre Reinforced Polypropylene Composites. IOP Conf. Ser. Mater. Sci. Eng. 2020, 961, 012013. [CrossRef]

154. Juan, R.S.; Kurniawan, C.; Marbun, J.; Simamora, P. Mechanical properties of brake pad composite made from candlenut shell and coconut shell. J. Phys. Conf. Ser. 2020, 1428, 012018. [CrossRef] 
155. Agunsoye, J.O.; Aigbodion, V.S. Bagasse filled recycled polyethylene bio-composites: Morphological and mechanical properties study. Results Phys. 2013, 3, 187-194. [CrossRef]

156. Liu, Y.; Wang, L.; Liu, D.; Ma, Y.; Tian, Y.; Tong, J.; Senthamaraikannan, P.; Saravanakumar, S. Evaluation of wear resistance of corn stalk fiber reinforced brake friction materials prepared by wet granulation. Wear 2019, 432-433, 102918. [CrossRef]

157. Satapathy, B.K.; Bijwe, J. Performance of friction materials based on variation in nature of organic fibres Part I. Fade and recovery behaviour. Wear 2004, 257, 573-584. [CrossRef]

158. Mishra, V.; Biswas, S. Three-body abrasive wear behavior of short jute fiber reinforced epoxy composites. Polym. Compos. 2016, 37, 270-278. [CrossRef]

159. Sun, C.; Liu, A.; Du, G. Plasma treatment of bamboo fibers on the tribological property of polyimide composite filled with graphite. Surf. Interface Anal. 2018, 50, 234-239. [CrossRef]

160. Marewad, D.S.; Singh, G.P.; Adivarekar, R.V. Asbestos free brake pad using Micro cellulose fibre for automotive industry. Int. J. Adv. Res. Ideas Innov. Technol. 2018, 4, 685-690.

161. Tavangar, R.; Moghadam, H.A.; Khavandi, A.; Banaeifar, S. Comparison of dry sliding behavior and wear mechanism of low metallic and copper-free brake pads. Tribol. Int. 2020, 151, 106416. [CrossRef]

162. Sai Krishnan, G.; Pravin Kumar, J.; Shanmugasundar, G.; Vanitha, M.; Sivashanmugam, N. Investigation on the alkali treatment of Demostachya Bipinnata fibers for automobile applications-A green composite. Mater. Today Proc. 2020, 43, 828-831. [CrossRef]

163. Ganesh Babu, L. Influence of benzoyl chloride treatment on the tribological characteristics of Cyperus pangorei fibers based non-asbestos brake friction composites. Mater. Res. Express 2020, 7, 015303. [CrossRef]

164. Bajpai, P.K.; Singh, I.; Madaan, J. Tribological behavior of natural fiber reinforced PLA composites. Wear 2013, 297, 829-840. [CrossRef]

165. Mylsamy, B.; Chinnasamy, V.; Palaniappan, S.K.; Subramani, S.P.; Gopalsamy, C. Effect of surface treatment on the tribological properties of Coccinia Indica cellulosic fiber reinforced polymer composites. J. Mater. Res. Technol. 2020, 9, 16423-16434. [CrossRef]

166. Akıncıoğlu, G.; Öktem, H.; Uygur, I.; Akıncıoğlu, S. Determination of Friction-Wear Performance and Properties of Eco-Friendly Brake Pads Reinforced with Hazelnut Shell and Boron Dusts. Arab. J. Sci. Eng. 2018, 43, 4727-4737. [CrossRef]

167. Sim, J.; Park, C.; Moon, D.Y. Characteristics of basalt fiber as a strengthening material for concrete structures. Compos. Part B Eng. 2005, 36, 504-512. [CrossRef]

168. Jacob Moses, A.; Suresh Babu, A.; Ananda Kumar, S. Analysis of physical properties and wear behavior of phenol formaldehydeBasalt fiber reinforced brake pad. Mater. Today Proc. 2020, 33, 1128-1132. [CrossRef]

169. Zhao, X.; Ouyang, J.; Yang, H.; Tan, Q. Effect of basalt fibers for reinforcing resin-based brake composites. Minerals 2020, 10, 490. [CrossRef]

170. Ilanko, A.K.; Vijayaraghavan, S. Wear behavior of asbestos-free eco-friendly composites for automobile brake materials. Friction 2016, 4, 144-152. [CrossRef]

171. Atmika, I.K.A.; Subagia, I.D.G.A.; Surata, I.W.; Sutantra, I.N. Hardness and wear rate of basalt/alumina/shellfish powder reinforced phenolic resin matrix hybrid composite brake lining pads. IOP Conf. Ser. Mater. Sci. Eng. 2019, 539, 012012. [CrossRef]

172. Abutu, J.; Lawal, S.A.; Ndaliman, M.B.; Lafia-Araga, R.A.; Adedipe, O.; Choudhury, I.A. Effects of process parameters on the properties of brake pad developed from seashell as reinforcement material using grey relational analysis. Eng. Sci. Technol. Int. J. 2018, 21, 787-797. [CrossRef]

173. Maleque, M.A.; Atiqah, A.; Atiqah, A. Development and Characterization of Coir Fibre Reinforced Composite Brake Friction Materials. Arab. J. Sci. Eng. 2013, 38, 3191-3199. [CrossRef]

174. Li, M. Palm Fiber-Reinforced Environment-Friendly Type Brake Pad and Preparation Method Thereof. 2013. Available online: https:/ / worldwide.espacenet.com/patent/search/family/049689956/publication/CN103436236A?q=Palm\%20fiberreinforced\%20environment-friendly\%20type \%20brake\%20pad\%20and\%20preparation\%20method\%20thereof (accessed on 20 January 2022).

175. Li, M. Brake Pad for Flax Fiber Reinforced Environmental-Friendly Car and Preparation Method Thereof. 2013. Available online: https:/ / patents.google.com/patent/CN103361031B/en (accessed on 20 January 2022).

176. Huang, X. Environment-Friendly Brake Pad. 2015. Available online: https://worldwide.espacenet.com/patent/search/family/ 054273075/publication/CN104976258A?q=pn\%3DCN104976258A (accessed on 20 January 2022).

177. Li, M. Automobile Brake Pad Mixing with Bamboo Fibers. 2013. Available online: https://worldwide.espacenet.com/patent/ search/family/049648539/publication/CN103423345A?q=pn\%3DCN103423345A (accessed on 20 January 2022).

178. Jiang, Y. Hibiscus Manihot Fiber Reinforced Environment-Friendly Brake Pad and Preparation Method Thereof. 2016. Available online: https://worldwide.espacenet.com/patent/search/family/057090887/publication/CN106015400A?q=Hibiscus\%20 manihot $\% 20$ fiber $\% 20$ reinforced $\% 20$ environment-friendly $\% 20$ brake $\% 20$ pad $\% 20$ AND $\% 20$ preparation $\% 20$ method $\% 20$ thereof $\%$ 202016 (accessed on 20 January 2022).

179. Li, X. Method for Preparing Brake Pad from Basalt Fiber. 2016. Available online: https://worldwide.espacenet.com/patent/ search/family/058837619/publication/CN106641049A?q=pn\%3DCN106641049A (accessed on 20 January 2022).

180. Bakirdere, S.; Orenay, S.; Korkmaz, M. Effect of Boron on Human Health. Open Miner. Process. J. 2014, 3, 54-59. [CrossRef]

181. Turkez, H.; Geyikoglu, F.; Tatar, A.; Keles, M.S.; Kaplan, I. The effects of some boron compounds against heavy metal toxicity in human blood. Exp. Toxicol. Pathol. 2012, 64, 93-101. [CrossRef] 
182. Jeganmohan, S.; Sugozu, B. Usage of powder pinus brutia cone and colemanite combination in brake friction composites as friction modifier. Mater. Today Proc. 2019, 27, 2072-2075. [CrossRef]

183. Sugozu, I.; Mutlu, I.; Sugozu, K.B. The effect of ulexite to the tribological properties of brake lining materials. Polym. Compos. 2018, 39, 55-62. [CrossRef]

184. Jajuha, U.; Ahlawat, V. Investigation of three-body abrasive wear characteristics of white ark shell powder. Mater. Today Proc. 2020, 44, 4315-4323. [CrossRef]

185. Pinca Bretotean, C.; Lemle, D.; Szabo, A.; Bretotean, C.P.; Lemle, L.D.; Szabo, A. Ecological composites materials for brake pads using shells as filler material. Mater. Plast. 2019, 56, 588. [CrossRef]

186. Akıncıoğlu, G.; Akıncıoğlu, S.; Öktem, H.; Uygur, İ. Wear response of non-asbestos brake pad composites reinforced with walnut shell dust. J. Aust. Ceram. Soc. 2020, 56, 1061-1072. [CrossRef]

187. Obot, M.U.; Yawas, D.S.; Aku, S.Y. Development of an abrasive material using periwinkle shells. J. King Saud Univ.-Eng. Sci. 2017, 29, 284-288. [CrossRef]

188. Yawas, D.S.; Aku, S.Y.; Amaren, S.G. Morphology and properties of periwinkle shell asbestos-free brake pad. J. King Saud Univ.-Eng. Sci. 2016, 28, 103-109. [CrossRef]

189. Solomon, W.C.; Lilly, M.T.; Sodiki, J.I. Production of Asbestos-free Brake Pad Using Groundnut Shell as Filler Material. Int. J. Sci. Eng. Invent. 2018, 4, 21-to. [CrossRef]

190. Keskin, A. Investigation of using natural zeolite in brake pad. Sci. Res. Essays 2011, 6, 4893-4904. [CrossRef]

191. Chandradass, J.; Surabhi, M.A.; Sethupathi, P.B.; Jawahar, P. Development of low cost brake pad material using asbestos free sugarcane bagasse ash hybrid composites. Mater. Today Proc. 2021, 45, 7050-7057. [CrossRef]

192. Primaningtyas, W.E.; Sakura, R.R.; Suheni; Syafi'I, I.; Adhyaksa, A.A.G.A.D. Asbestos-free Brake Pad Using Composite Polymer Strengthened with Rice Husk Powder. IOP Conf. Ser. Mater. Sci. Eng. 2019, 462, 012015. [CrossRef]

193. Bahari, S.A.; Isa, K.H.; Kassim, M.A.; Mohamed, Z.; Othman, E.A. Investigation on hardness and impact resistance of automotive brake pad composed with rice husk dust. AIP Conf. Proc. 2012, 1455, 155-161.

194. Singh, T.; Patnaik, A.; Gangil, B.; Chauhan, R. Optimization of tribo-performance of brake friction materials: Effect of nano filler. Wear 2015, 324-325, 10-16. [CrossRef]

195. Singh, T.; Rathi, M.K.; Patnaik, A.; Chauhan, R.; Ali, S.; Fekete, G. Application of waste tire rubber particles in non-asbestos organic brake friction composite materials. Mater. Res. Express 2019, 6, 035703. [CrossRef]

196. Manoharan, S.; Shihab, A.I.; Alemdar, A.S.A.; Babu, L.G.; Vijay, R.; Lenin Singaravelu, D. Influence of recycled basalt-aramid fibres integration on the mechanical and thermal properties of brake friction composites. Mater. Res. Express 2019, 6, 115310. [CrossRef]

197. Singh, T.; Patnaik, A.; Chauhan, R. Optimization of tribological properties of cement kiln dust-filled brake pad using grey relation analysis. Mater. Des. 2016, 89, 1335-1342. [CrossRef]

198. Mohanty, S.; Chugh, Y.P. Development of fly ash-based automotive brake lining. Tribol. Int. 2007, 40, 1217-1224. [CrossRef]

199. Öztürk, B.; Mutlu, T. Effects of Zinc Borate and Fly Ash on the Mechanical and Tribological Characteristics of Brake Friction Materials. Tribol. Trans. 2016, 59, 622-631. [CrossRef]

200. Dadkar, N.; Tomar, B.S.; Satapathy, B.K.; Patnaik, A. Performance assessment of hybrid composite friction materials based on flyash-rock fibre combination. Mater. Des. 2010, 31, 723-731. [CrossRef]

201. Wang, T.M.; Hou, K.H.; Chang, Y.T.; Lee, W.C.; Ger, M. Der The preparation of slag fiber and its application in heat resistant friction composites. Mater. Des. 2010, 31, 4296-4301. [CrossRef]

202. Tiwari, A.; Jaggi, H.S.; Kachhap, R.K.; Satapathy, B.K.; Maiti, S.N.; Tomar, B.S. Comparative performance assessment of cenosphere and barium sulphate based friction composites. Wear 2014, 309, 259-268. [CrossRef]

203. Tasala Gradin, K.; Åström, A.H. Evaluation of an Eco Audit tool-through an LCA of a novel car disc brake. In Proceedings of the DS 91 Proceedings of NordDesign 2018, Linköping, Sweden, 14-17 August 2018.

204. Hu, X.; Wang, N.; Pan, P.; Bai, T. Performance evaluation of asphalt mixture using brake pad waste as mineral filler. Constr. Build. Mater. 2017, 138, 410-417. [CrossRef]

205. Bai, T.; Song, Z.; Wang, H.; Wu, Y.; Huang, W. Performance evaluation of metakaolin geopolymer modified by different solid wastes. J. Clean. Prod. 2019, 226, 114-121. [CrossRef] 